Article

\title{
Assessment of Performance and Challenges in Use of Commercial Automated Sorting Technology for Plastic Waste
}

\author{
Cesar Lubongo ${ }^{1}$ and Paschalis Alexandridis $1,2, *$ (ID
}

Citation: Lubongo, C.; Alexandridis, P. Assessment of Performance and Challenges in Use of Commercial Automated Sorting Technology for Plastic Waste. Recycling 2022, 7, 11. https://doi.org/10.3390/ recycling7020011

Academic Editors: Michele John and Wan-Ting (Grace) Chen

Received: 29 December 2021 Accepted: 12 February 2022 Published: 23 February 2022

Publisher's Note: MDPI stays neutral with regard to jurisdictional claims in published maps and institutional affiliations.

Copyright: (C) 2022 by the authors. Licensee MDPI, Basel, Switzerland. This article is an open access article distributed under the terms and conditions of the Creative Commons Attribution (CC BY) license (https:// creativecommons.org/licenses/by/ $4.0 /)$.
1 Department of Chemical and Biological Engineering, University at Buffalo, The State University of New York (SUNY), Buffalo, NY 14260-4200, USA; cesarlub@buffalo.edu

2 Department of Civil, Structural and Environmental Engineering, University at Buffalo, The State University of New York (SUNY), Buffalo, NY 14260-4300, USA

* Correspondence: palexand@buffalo.edu

\begin{abstract}
Recycling plastic is an important step towards a circular economy. Attaining high-quality recycled plastics requires the separation of plastic waste by type, color, and size prior to reprocessing. Automated technology is key for sorting plastic objects in medium- to high-volume plants. The current state of the art of commercial equipment for sorting plastic as well as challenges faced by Material Recovery Facilities (MRFs) to sort post-consumer plastics are analyzed here. Equipment for sorting plastic recyclables were identified using publicly available information obtained from manufacturers' websites, press releases, and journal articles. Currently available automated sorting equipment and artificial intelligence (AI)-based sorters are evaluated regarding their functionality, efficiency, types of plastics they can sort, throughput, and accuracy. The information compiled captures the progress made during the ten years since similar reports were published. A survey of MRFs, reclaimers, and brokers in the United States identified methods of sorting used for plastic, sorting efficiency, and current practices and challenges encountered at MRFs in sorting plastic recyclables. The commercial sorting equipment can address some of the challenges that MRFs face. However, sorting of film, multilayered, blended, or mixed-material plastics is problematic, as the equipment is typically designed to sort single-component materials. Accordingly, improvements and/or new solutions are considered necessary.
\end{abstract}

Keywords: polymer; optical sorter; waste management; recycling; circular economy; sustainability

\section{Introduction}

Post-consumer plastics are difficult to manage with the current recycling infrastructure, mainly due to the large volume of waste generated, combined with the complexity of effectively sorting different types, shapes, and sizes of plastics for recycling. In 2017, the United States produced 35.4 million tons of plastics [1], of which only 2.96 million tons $(\sim 8.4 \%)$ were recycled. Higher recycling rates of post-consumer plastics can be achieved by improving sorting efficiency. Poorly sorted plastics result in higher reprocessing costs and a lower value for reprocessed plastics [2]. In order to achieve circularity and improve the utilization of resources, it is necessary to reduce the amount of post-consumer plastics that ends up in landfills or released into the environment.

Plastics can be recycled via mechanical or chemical means [3,4]. Mechanical recycling of plastic involves a sequence of steps, namely, sourcing, sorting, washing, shredding, identification, and separation of different plastic types, and extrusion and compounding of desired types of plastic (typically HDPE). For mechanical recycling, plastics need to be separated by type and color before reprocessing. For municipal solid waste, separation by type is performed at the Materials Recovery Facility (MRF) level, while industrial singletype plastics are typically handled by brokers. However, a few MRFs sort plastics from both municipal and industrial waste. Reclaimers obtain plastics sorted by MRFs and brokers for reprocessing into new plastic materials $[5,6]$. 
Plastics can be sourced from households and industry (e.g., manufacturing companies, retail stores, offices) through (1) single-stream, (2) mixed municipal waste, (3) dual-stream, (4) pre-sorted recyclables, or (5) container deposits [7]. Single-stream recycling is a system in which all recyclables (e.g., paper, fibers, plastics, metals, glass, and other containers) are sourced together using a single bin, a method commonly used in the US [8,9]. Single-stream recycling reportedly helped increase participation in recycling from $22 \%$ in 2005 to $73 \%$ in 2014 [9]. However, this method is often associated with cross-contamination levels in recovered plastics [9]. The mixed municipal waste consists of a mixture of waste from all places, including household waste, retail stores and other businesses, office wastes, miscellaneous waste, and non-hazardous waste. Dual-stream is sourced into separate bins by the depositor (i.e., mixed paper and cardboard in one bin, and commingled materials, such as glass, plastics, cans, and jars in another) [9]. Pre-sorted recyclables are materials (i.e., plastic waste) sorted by MRFs that are sent to a secondary MRF (for further sorting) or to reclaimers. Container deposits (i.e., "Bottle Bills") work by adding a fee on top of a beverage product that is later refunded to the customer when the empty container is returned to an authorized redemption center for recycling.

The types of plastics sorted at MRFs are (1) poly(ethylene terephthalate) (PET), (2) high-density polyethylene (HDPE), (3) poly(vinyl chloride) (PVC), (4) low-density poly-ethylene (LDPE), (5) polypropylene (PP), (6) polystyrene (PS), and (7) other, where the numbers 1, 2, . , 7 refer to the Plastic Identification Codes [10]. Even though all these types of plastics have the potential to be sorted, most have little to no market value, except for PET and HDPE. The "residual" plastic left after the selection of valuable plastic (such as PET and HDPE) is typically landfilled. A report by Vedantam et al. [11] documented the drastic difference between the amount of HDPE recovered in New York State compared to the amount of PVC, LDPE, PS, and other plastics. The amount of PVC processed in New York State in 2019 was about 240,015 tons, 177,260 tons for LDPE and PS, and 7250 tons for others. The recovered amount of PVC, LDPE, PS, and other plastics are much lower than the amount of HDPE (colored HDPE 502,845 tons, natural HDPE 20,138) processed in the same year in New York State by brokers and reclaimers [11].

At the MRF level, post-consumer plastics can be sorted manually by operators or mechanically by exploiting differences in the optical, chemical, or electrostatic properties of materials [12]. The wide variety of plastic types makes it hard for MRF operators to efficiently distinguish plastics visually; thus, automated sorters are favored for medium- to high-volume MRFs. Automated sorting involves methods such as air classification, eddy current device, disc screen, magnetic separator, traveling chain curtains, trommel screens, optical sorters, and robotics [13]. The traditional sorters, such as magnetic and eddy currents, process waste mixtures to remove ferrous and non-ferrous materials. Separation of plastics by type, color, shape, and/or texture requires specialized equipment such as optical sorters and/or artificial intelligence (AI)-equipped sorters [14-16]. Sorting method varies based on the product(s) of interest, thus driving the choice of the best applicable method or technology. Optical sorters and/or AI-equipped sorters can sometimes be combined to improve product yield or sorting efficiency [16]. However, many MRFs rely on manual sorting to achieve high purity levels. This can be expensive and time-consuming for high volumes of waste, and it endangers operators' health due to toxic additives $[17,18]$. In contrast, automated sorting is more efficient and can be cost-effective [17]. More versatile sorting technologies are needed to efficiently separate plastics based on resin type and grade.

The current state-of-the-art of plastic sorting equipment together with challenges faced by MRFs operating in the United States to sort post-consumer plastics are analyzed here. The previous reports published on plastic sorting equipment (by 4R Sustainability [19] and by Delavelle [20]) date from over ten years ago. Recent advances in technology and increasing pressure to recycle higher amounts of plastics motivate this effort to compile an updated inventory of established and emerging sorting equipment, and to ascertain whether this equipment can meet challenges reported at the MRF level. To this end, we evaluated both conventional systems (i.e., optical sorters) and emerging sorting equipment 
(i.e., AI sorting robots) using metrics on their efficiency, types of plastic sorted, size of plastic sorted, and ability to sort by color.

The following section describes the methodology used to obtain data on sorting equipment and provides an overview of our survey of MRFs. Physical principles enabling plastic materials to be sorted by type are outlined in the next section. Challenges encountered by MRFs to sort plastics and factors affecting sorting efficiency are then discussed, based on results from the survey we have conducted. Next, the inventory of sorting equipment is organized as sorters for whole plastic objects, sorters for films, flake sorters, and AI-based sorters. Equipment efficiency, type and size of plastic sorted, and throughput are reported. Finally, conclusions are presented on whether limitations at MRFs can be addressed with currently available technologies.

\section{Methodology}

This study synthesized and analyzed two streams of information: (1) availability and capabilities of automated sorting equipment used for plastic waste, obtained from suppliers of said equipment, and (2) utilization of sorting equipment at MRFs, sorting efficiency, and challenges faced, obtained from a survey of companies active in the field.

Equipment for sorting plastic recyclables were identified using publicly available information obtained from manufacturers' websites, press releases, and journal articles. A search for sorting equipment and companies was conducted using Google, Google Scholar, Web of Science, Science Direct, and Engineering Village databases; with keywords such as "sorting equipment manufacturers or companies", "optical sorters", "plastic sorters", "plastic sorting machines", "sorting equipment', and "plastic recycling". Contact information of sorting equipment suppliers is reported in Appendix A. The companies listed come from North America and Europe. Our search was conducted in the English language; hence, it may not have captured companies in, e.g., China. The information collected here reveals the progress made during the 10 years since similar reports were published. This information is further used to assess whether challenges reported by MRFs in our survey (see next paragraph) can be addressed by currently available technologies or emerging technologies. The gap between the sorting efficiency reported by manufacturers and sorting efficiency obtained at MRFs is also obtained and reported here.

Limitations and challenges encountered at MRFs in sorting plastic recyclables were identified in a survey conducted by our team and through interviews with industry professionals. The survey was developed using Qualtrics XM software and was distributed to over 100 recycling entities (MRFs, reclaimers, and brokers) in the United States during the period August 2020 to March 2021. The list of companies surveyed was developed through Google search and magazines: Waste Today (https://www.wastetodaymagazine.com/ article/largest-north-american-material-recovery-facilities last accessed on 12 February 2022), Recycling Today (https: / / www.recyclingtoday.com/ last accessed on 12 February 2022), and Waste 360 (https:/ / www.waste360.com/ last accessed on 12 February 2022). The companies were contacted prior to sending the survey, and the survey was sent out to companies that showed interest in participating. Survey takers were guided through a series of quantitative and qualitative questions linked to their position in the broader plastics supply chain. Note that businesses self-identified their role in the plastics supply chain and responded to presented questions accordingly. A total of 22 responses were obtained (from 12 reclaimers, $7 \mathrm{MRFs}$, and 3 brokers), which is a satisfactory response rate for such a survey that required significant effort to collect valuable responses.

Survey questions were designed to understand the sources of plastic recyclables, amounts of plastics processed and recovered by type, methods used to sort plastic, size and types of plastics sorted, types of sorting technology in use, sorting efficiency, the technological developments that MRFs hope to see, top contaminants, average percentage contamination in the bales, the quantity of residual/landfilled material, and the types of plastic objects produced by reclaimers from recycled plastic. Specifically, survey questions were organized into 6 sections. Section 1 involved data on the type of facility (i.e., MRF, 
broker, or recycler) and the location of the facility. Facility locations would help estimate the amount of plastic processed from different regions. In Section 2, the waste sourcing method was designed to understand the impact of sourcing methods of plastic (i.e., municipal waste (single stream), dual stream, industrial source) on the quality of sorted plastic. Section 3 was based on the separation process used at MRFs, whether manual, automated separation, or both manual and automated sorting. If automated sorting or a combination of automated and manual sorting was selected, it was asked to provide details on the type of sorting equipment employed (magnetic separator, eddy current device, disc screen, trommel, screen, vibrating screen, traveling chain curtains, air classification system, and optical sorting equipment and the brand of the optical sorting equipment). Optical sorting equipment details would allow the comparison of sorting efficiency at the MRF level to the sorting efficiency reported by the equipment manufacturer. Section 4 was based on the challenges and limitations associated with sorting plastic waste at MRFs and how these challenges affect MRFs operations. Moreover, MRFs were asked to provide improvement recommendations in current or emerging sorting technologies that would benefit them and improve sorting efficiency. In Section 5, MRFs were asked to provide data on the type (e.g., PET), form (rigid or film), and amount of plastic sorted. MFRs were also asked to provide details and the fate of produced residuals. Section 6 was based on contamination on sorted plastic or efficiency of sorting technologies and their impact at the MRF level. Examples of survey questions are included in Appendix B. Note that only the parts of the survey that pertain to automated sorting are discussed here.

\section{Plastic Type Identification Principles}

In order to achieve the US national recycling rate target of $50 \%$ by 2030 , with specific goals of reducing contamination in recycled content and improving the quality of recycled materials [21], a technology improvement is expected in order to keep pace with today's diverse and changing waste system. Eriksen et al. [22] reported that $17 \%$ to $100 \%$ of postconsumer plastic could be recovered with an improved source separation system and improved separation efficiency at the MRF level. The same study concluded that $<42 \%$ of plastic could be sorted with current technology [22].

Current technologies used to sort plastic waste are based on Near Infrared (NIR), Xray Fluorescence (XRF), and VIS (color analysis by camera or spectro-colorimeter) [23-25]. Some other technologies, such as mid-infrared (MIR), shape recognition, hyperspectral imaging, electrostatic separators, and barcode scanners, show potential for sorting plastic recyclables but are yet to be used in large scale plastic sorting [26-29]. The wavelength ranges for each optical technology vary, from lower (X-ray) to higher wavelengths for NIR and Microwave (Figure 1). The three key methods (i.e., NIR, XRF, VIS) have different advantages in sorting different types of plastic, as outlined below. In general, optical sorting works because, when light reaches an object, some light is reflected, and some is absorbed. Different materials reflect and absorb light at different wavelengths. The reflected light minus the absorbed light produces a signature or fingerprint, which is unique to the chemical makeup of the object, allowing plastic objects to be sorted based on their chemical composition [30,31].

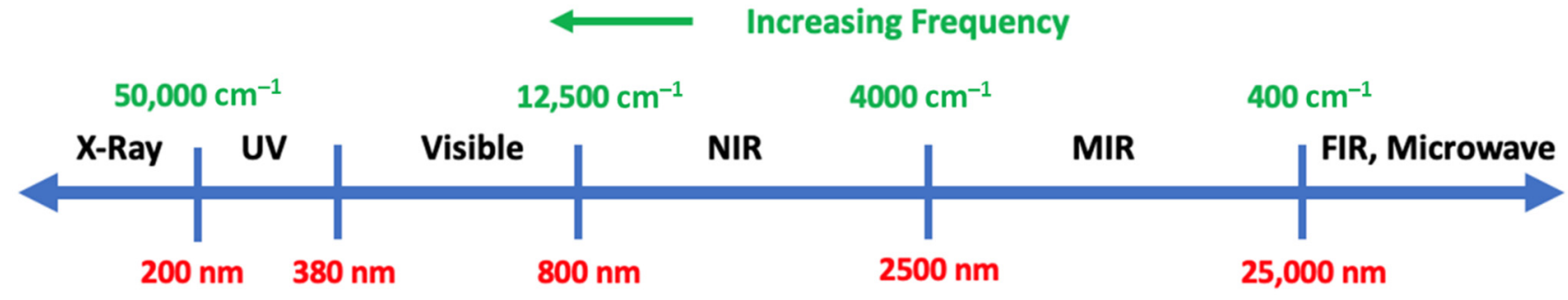

Increasing Wavelength

Figure 1. Wavelength range for different optical technologies (adapted from [20,32]). 
Near InfraRed (NIR) based sorters employ rapid, non-destructive analysis to sort post-consumer PET, HDPE, PP, and PS [28,30]. NIR sensors detect variation in absorption, transmittance, and scattering of light in infrared wavelengths produced by different materials, which enables it to sort by plastic type $[18,33]$. The sorting of plastics waste can be influenced by the plastic color, surface texture, and shape, as these properties can influence the intensity of the obtained spectra [27,34]. NIR spectroscopy (wavelengths between 0.8 and $2.5 \mu \mathrm{m}$, Figure 1) has many advantages, such as remote high-speed measurements, the high penetration depth of the NIR radiation, and a high signal-to-noise ratio [28]. However, NIR optical sorters are not effective in sorting black plastics because the carbon black pigment interferes with the reflected light, making identification impossible because most light is absorbed. Similarly, NIR optical sorters perform poorly in sorting plastics containing brominated flame retardants (BFRs) [26].

$\mathrm{X}$-ray Fluorescence $(\mathrm{XRF})$ based sorters: $\mathrm{X}$-rays penetrate materials and are absorbed or scattered depending on the material [18,35]. XRF works by projecting primary $\mathrm{X}$-rays onto the plastic under analysis, and measures the fluorescent $\mathrm{X}$-ray emitted at another wavelength by the elements present in the plastic. Each element is characterized by a unique fingerprint (spectrum), making identification of heavy elements such as chlorine and bromine possible [19]. XRF sorters are widely used to sort PVC and plastics containing BFRs [18]. However, the implementation of XRF-based sorters at an industrial level is often limited to the separation of PVC from PET [36].

Vision Technology (VIS): Optical sorting or color analysis by camera sort plastics by color. Camera-based sensors are used for identification based on the surface appearance of materials $[13,37]$. Commonly used technologies are the prism-coupled color camera system and visible spectrometry [20]. The prism-coupled color camera system works by measuring colors (red, green, and blue) based on intensity. Visible spectrometry works by analyzing the total range of the visible spectrum, thus accurately characterizing all colors [20]. In order to assess whether current sorting equipment can address the challenges reported by MRF operators, we evaluated both current systems (i.e., optical sorters) and emerging sorting equipment (i.e., AI sorting robots) using metrics on their efficiency, types of plastic sorted, size of plastic sorted, and ability to sort by color [13,37].

\section{Challenges in Sorting Plastics}

This section describes the main challenges of sorting post-consumer plastic waste, as reported by surveyed MRFs that are based in the United States. Regarding sorting technology, 29\% of the seven MRFs responding to our survey use fully automated sorting facilities with little human input, $28 \%$ rely heavily on manual sorting, and $43 \%$ use both manual and automated sorting, as illustrated in Figure 2.

MRFs reported difficulties in sorting a variety of plastics. Survey results indicate that 5 out of 12 plastic reclaimers (i.e., the entities to which the MRFs send their sorted plastics) reported concerns about the quality of bales provided by MRFs, and indicated that up to $5 \%$ of bales from MRFs are rejected due to poor sorting. Low bale quality is often associated with the presence of labels on plastic materials, multilayered films, mixed polymers, wires, and incorrectly sorted individual types of polymers. One reclaimer indicated that up to $35 \%$ of colored plastic is sorted incorrectly and therefore wasted.

Limitations reported by MRFs in their survey responses are summarized in Table 1. MRFs that rely on manual sorting of plastic recyclables reported a low throughput of materials. Automated sorting could help resolve throughput limitations faced by such facilities. Another challenge for MRFs relying on manual sorting of plastic recyclables was the growing number and types of plastic reducing sorting efficiency (see Table 1). MRFs using automated sorting (or a combination of automated and manual sorting) reported that tanglers wrapping around sorting equipment presented a challenge. Tanglers are materials such as ropes, cords, plastic films, or chains that become wrapped around sorting equipment at MRFs, affecting the functionality of equipment and/or causing the shutdown of operations $[38,39]$. Films (e.g., plastic bags, wrapping films) are flexible plastic 
materials (mostly made of LDPE or HDPE), often used for packaging (e.g., bags, pouches) or wrappers $[38,40]$. Bale de-wiring technology is reported to be needed by MRFs using automated sorters due to shutdowns caused by wires and tanglers, which can occur up to five times a day and last up to $30 \mathrm{~min}$. MRFs and reclaimers have reported that films are difficult to sort and are generally dirty, with high contamination rates. Film sorting challenges can occur due to technology limitations at MRFs, coupled with an insufficient supply of films. Reclaimers indicated that films are costly to reprocess due to intensive washing requirements.

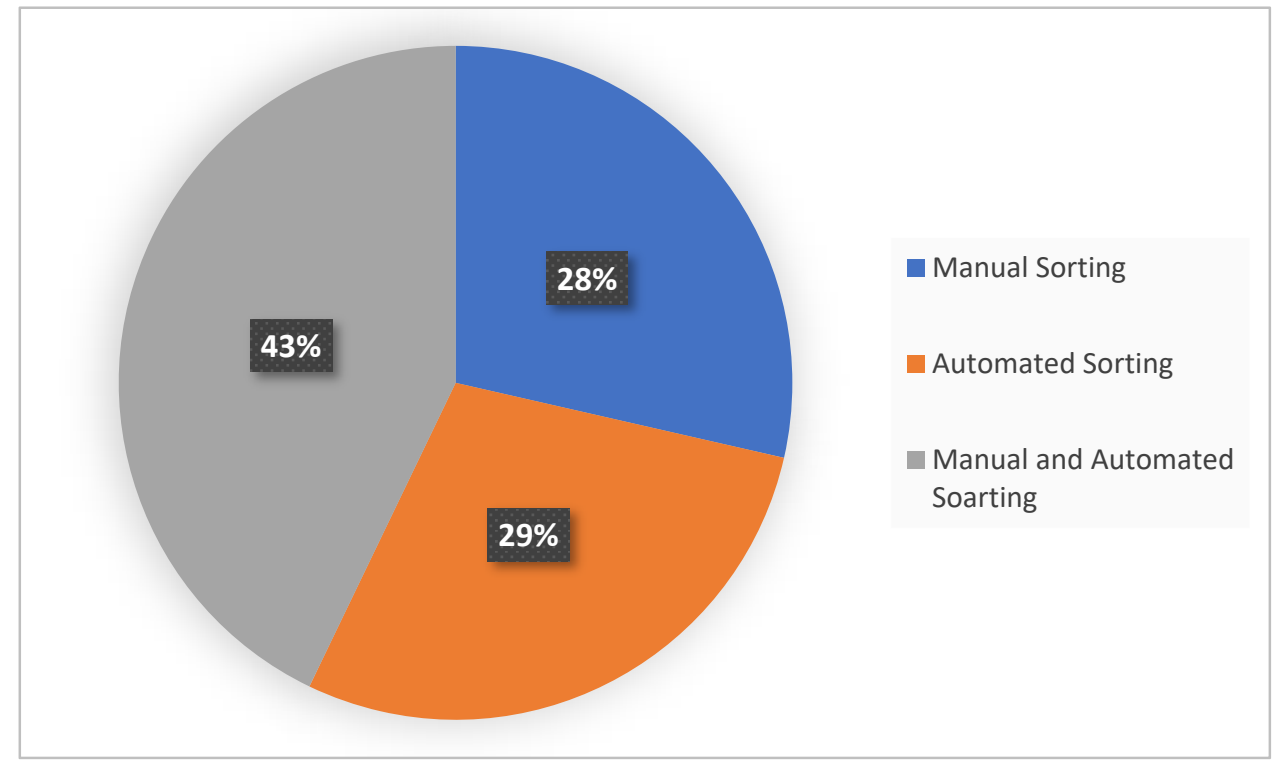

Figure 2. Breakdown of sorting methodologies currently used at MRFs in the U.S.

Table 1. Common limitations in sorting plastic wastes reported by MRFs.

\begin{tabular}{ll}
\hline MRFs & \multicolumn{1}{c}{ Reported Limitations } \\
\hline MRF1 & Throughput constraints for manual sorting MRFs \\
\hline MRF 2 & Plastic bags and film wrapping around equipment (Tanglers) \\
\hline MRF 3 & Tanglers \\
MRF 4 & $\begin{array}{l}\text { Tanglers and the growing number and types of plastics make it } \\
\text { inefficient (black plastics). Difficult to identify the type of plastic } \\
\text { when it is not a bottle tub jug or lid }\end{array}$ \\
\hline
\end{tabular}

Another concern identified in the survey was the inability to sort black plastics. Black plastics are reportedly a challenge to correctly sort at MRFs [41,42]. Industry professionals (Scott Farling, personal communication, 4 June 2020) mentioned that black plastics are often considered residuals at MRFs; they are difficult to sort and have low market value. A few technologies are reported to sort black plastics [42]; however, no indication of black plastic sorting efficiency was reported by sorting equipment manufacturers.

Figure 3 shows photographs from manual sorting at MRFs, automated sorting MRFs, and some of the limitations faced by MRFs. 


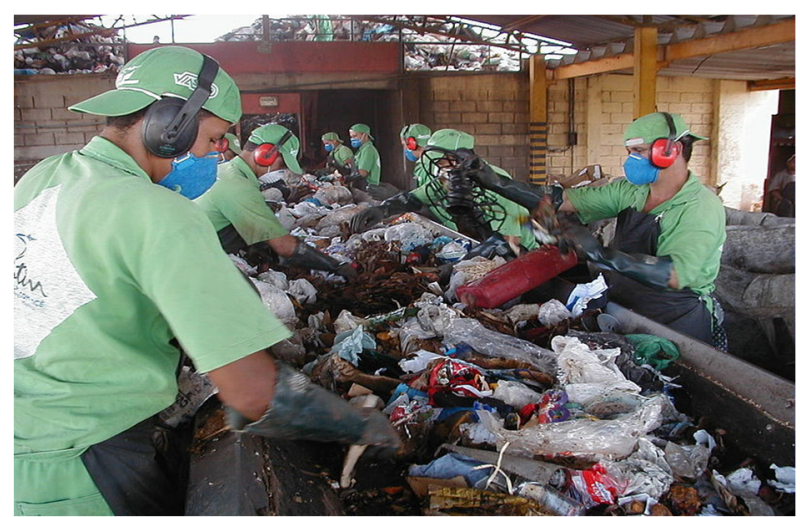

(a)

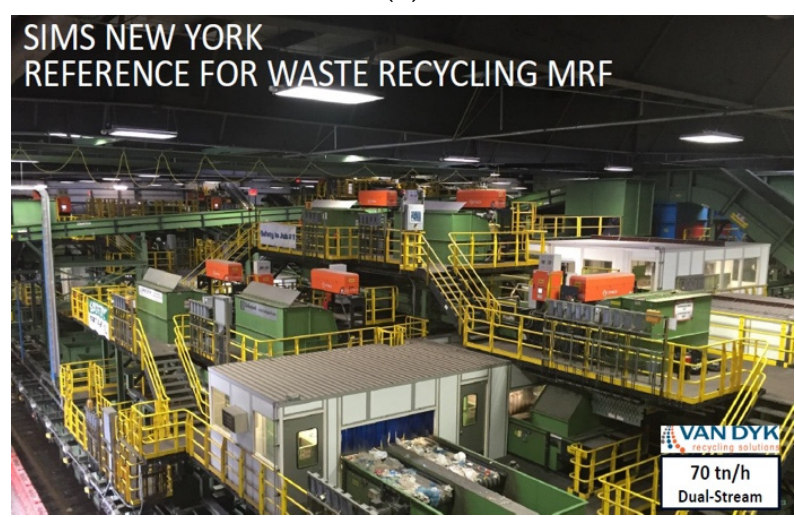

(c)



(b)

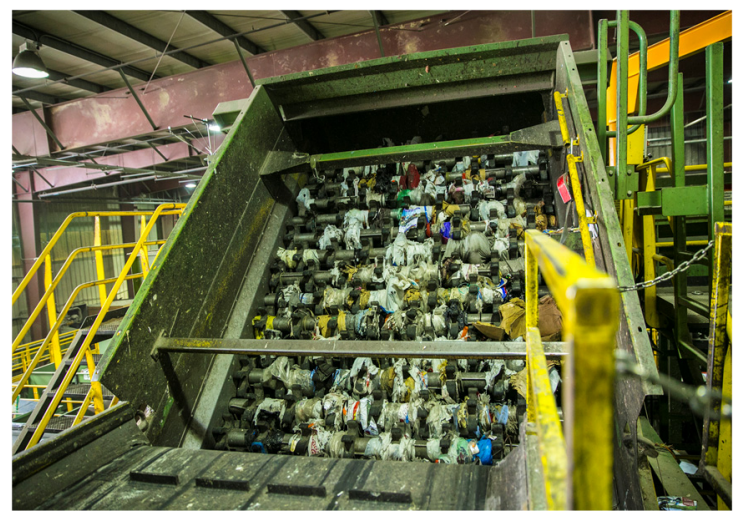

(d)

Figure 3. (a) Manual sorting process at MRFs, (b) automated sorting using optical sorter, (c) overview of an MRF sorting facility using multiple automated sorters, and (d) tanglers as a key problem encountered by MRFs. Extracted from cleantechloops, steinertglobal, simsmunicipal, mydisposal.

\section{Factors Affecting Sorting Efficiency at the MRF Level}

Sorting efficiency is affected by the composition of the incoming stream, the method of sourcing, sorting technology, and operational procedures at the MRF, as described below.

The composition of the incoming stream can directly relate to the method of sourcing, as materials can be sourced from household and industry (e.g., manufacturing companies, retail stores, offices) through (1) single-stream, (2) mixed municipal waste, (3) dual-stream, (4) pre-sorted recyclables, or (5) containers deposits [7].

Survey responses indicate that sourcing materials from container deposits ( $1 \%$ contamination) and industrial sources ( $0 \%$ contamination) resulted in higher sorting efficiency, compared to materials sourced using single stream (up to $12 \%$ contamination) or dual stream (up to 5\% contamination) (see Table 2). However, anecdotal evidence from MRFs that switched from single-stream to dual-stream recycling indicates that the purity level did not differ much from bales recovered from single and double-stream recycling. Additional data are required to confirm this.

Regarding sorting technology, manual and automated sorting have different efficiencies, according to survey respondents. MRFs using manual sorting reported less downtime and higher sorting efficiency compared to MRFs employing automated sorting or a combination of automated and manual sorting. The higher sorting efficiency ( $>98 \%$ ) of manual sorting MRFs is related to the fact that one MRF uses manual sorting and receives pre-sorted plastics with a reduced presence of foreign materials (i.e., paper, glass, aluminum cans), while the second MRF using manual sorting sourced plastic from dual-stream waste. 
Table 2. Sorting efficiency based on collection method, stream type, and materials sources.

\begin{tabular}{|c|c|c|c|c|c|c|c|c|c|}
\hline MRF & $\begin{array}{l}\text { Post Industrial } \\
\text { Source (\%) }\end{array}$ & Stream Type & $\begin{array}{l}\text { Separation } \\
\text { Method }\end{array}$ & $\begin{array}{l}\text { Number of } \\
\text { Operators }\end{array}$ & Type of Plastic Sorted & $\begin{array}{l}\text { Challenges or } \\
\text { Limitations }\end{array}$ & $\begin{array}{l}\% \text { of Non-Glass } \\
\text { Materials from } \\
\text { Incoming Stream } \\
\text { That Is Landfilled }\end{array}$ & $\begin{array}{c}\text { Percent } \\
\text { Contamination }\end{array}$ & $\begin{array}{c}\text { What Type of } \\
\text { Technological } \\
\text { Development(s) Would } \\
\text { Benefit Your Facility? }\end{array}$ \\
\hline 1 & 0 & Dual Stream & $\begin{array}{l}\text { Manual } \\
\text { Separation }\end{array}$ & 100 & PET (\#1), LDPE (\#4) & $\begin{array}{l}\text { Time consuming; } \\
\text { throughput constraints, } \\
\text { high turnover }\end{array}$ & $0 \%$ & $1 \%$ for PET & Optical sorters \\
\hline 2 & 1 & Both & $\begin{array}{l}\text { Manual and } \\
\text { Automated } \\
\text { Separation }\end{array}$ & 30 & $\begin{array}{c}\text { PET (\#1), Natural HDPE (\#2), Colored } \\
\text { HDPE (\#2), LDPE (\#4), PP (\#5), Industrial } \\
\text { Scrap Plastic, } \\
\text { Other. (Obs. MRP-only \#2 pails and \#5 } \\
\text { pails, not all) }\end{array}$ & $\begin{array}{l}\text { Tanglers (plastic bags } \\
\text { and film) }\end{array}$ & $21 \%$ & & \\
\hline 3 & 5 & Single Stream & $\begin{array}{l}\text { Manual and } \\
\text { Automated } \\
\text { Separation }\end{array}$ & 22 & $\begin{array}{c}\text { PET (\#1), Natural HDPE (\#2), Colored } \\
\text { HDPE (\#2), } \\
\text { PVC (\#3), LDPE (\#4), PP (\#5), PS (\#6), } \\
\text { Other Plastics (\#7). [\#3 to \#7 are mixed] }\end{array}$ & Tanglers, material jam & $12 \%$ & $\begin{array}{l}9 \% \text { on avg for PET } \\
\text { and HDPE, and 9\% } \\
\text { for MPR \#3-7 }\end{array}$ & \\
\hline 4 & 20 & Single Stream & $\begin{array}{l}\text { Manual and } \\
\text { Automated } \\
\text { Separation }\end{array}$ & 12 & $\begin{array}{l}\text { PET (\#1), Natural HDPE (\#2), Colored } \\
\text { HDPE (\#2), Polypropylene (\#5), Other } \\
\text { Mixed Rigid Plastics (MRP) }\end{array}$ & $\begin{array}{l}\text { Tanglers, growing } \\
\text { number and types of } \\
\text { plastics }\end{array}$ & $8 \%$ & $\begin{array}{l}1 \% \text { for PET, natural } \\
\text { and colored HDPE, } \\
\text { PVC, and } 5 \% \text { for } \\
\text { other MRP }\end{array}$ & Optical sorters \\
\hline 5 & 5 & Both & $\begin{array}{l}\text { Automated } \\
\text { Separation }\end{array}$ & & $\begin{array}{l}\text { PET (\#1), Natural HDPE (\#2), Colored } \\
\text { HDPE (\#2), LDPE (\#4), Polypropylene } \\
\text { (\#5), Industrial Scrap Plastic, Mixed Rigid } \\
\text { Plastics (MRP), Plastic Films and } \\
\text { Bags (LDPE) }\end{array}$ & & $5 \%$ & & \\
\hline 6 & 100 & Dual & $\begin{array}{l}\text { Manual } \\
\text { Separation }\end{array}$ & 7 & $\begin{array}{c}\text { PET (\#1), Natural HDPE (\#2), Colored } \\
\text { HDPE (\#2) }\end{array}$ & $\begin{array}{l}\text { Overcapacity, Labor } \\
\text { Shortage }\end{array}$ & $2.96 \%$ & $\begin{array}{l}0 \% \text { for PET, } 0 \% \text { for } \\
\text { natural HDPE }\end{array}$ & Optical sorters \\
\hline 7 & 90 & Both & & & $\begin{array}{l}\text { PET (\#1), Natural HDPE (\#2), Colored } \\
\text { HDPE (\#2), PVC (\#3), LDPE (\#4), } \\
\text { Polypropylene (\#5), Polystyrene (\#6), } \\
\text { Other Plastics (\#7), Industrial Scrap } \\
\text { Plastic, Mixed Rigid Plastics (MRP), } \\
\text { Plastic Films and Bags (PET, HDPE, } \\
\text { LDPE, LLDPE) }\end{array}$ & & & & \\
\hline
\end{tabular}


Operational procedures at MRFs affect sorting efficiency. Running operations beyond designed capacity were reported as a problem by one respondent, as it reduced sorting efficiency. Running operations at greater than design capacity can indicate that processing more materials might be more important than sorting efficiency for this MRF.

In order to ensure quality plastics for reprocessing, it is important to limit contamination in sorted materials $(1.5 \%$ commonly used limit, $0.5 \%$ for China since the National Sword program was adopted) [43]. For example, as little as $50 \mathrm{ppm}$ of PVC can render an entire load of PET unmarketable $[9,17]$.

MRFs report that film separation from municipal solid waste is challenging [44]. Over $60 \%$ of survey respondents indicated this problem, and that the recovery rate is low and contamination in the sorted plastics is high $(>2 \%)$. Up to $5 \%$ of film bales received by reclaimers from MRFs are discarded or returned. Moreover, the demand for films is low, attributed to low quality associated with sorting challenges. One MRF that processes plastic films indicated that $<10 \%$ of sorted films are sold for reprocessing.

In Section 6, commercially available sorting equipment is evaluated as a potential remedy to the problems reported by MRFs in sorting plastic.

\section{Advances in Sorting Plastics}

\subsection{Sorting Equipment for Post-Consumer Plastics}

This section describes commercial sorting equipment for sorting mixed plastics. The optical sorters considered here utilize NIR, VIS (light- or camera-based), and XRF. Reported technologies are classified here based on criteria such as plastic identification method (e.g., NIR or XRF), primary application, throughput, whether they sort plastics by color, and/or by size, accuracy, and additional features (Table 3).

A total of 46 optical sorters manufactured by 17 companies have been identified. Of these, 22 can sort plastic by color, with 21 of them capable of sorting black plastics from other colors using a combination of NIR and VIS technologies. The number of optical sorters available has increased by $70 \%$ since $4 \mathrm{R}$ Sustainability released their report in 2011 [19]. The reported recovery efficiency that the sorters can attain is $99.99 \%$, depending on the input materials, with a wide range (up to 10 tons/h) of throughput capacities.

As discussed in the previous section, film separation from municipal solid waste is challenging for MRFs [44]. While traditional sorters designed to sort whole plastic items are not efficient in sorting plastic films and other 2D or lightweight materials, the technology exists to sort plastic films. In Table 4, nine specialist film sorters manufactured by eight companies are listed. None of these sorters was identified in the previous reports by 4R Sustainability [19] and by Delavelle [20]. These film sorters can reportedly attain an efficiency of $98 \%$, dependent on material inputs. Three of them have the ability to sort films by color, and most of them (67\% of sorters) use a combination of NIR and VIS. The film sorter Machina Cattura Sacchetti Film grabber Machine Unit by Amut Ecotech is not an optical sorter as it uses a blower to separate films or plastic bags, but is reported to be efficient in sorting films or plastic bags at the MRF level.

Flake sorting is an important step prior to reprocessing plastic, as it reduces contamination from foreign materials or unwanted plastics that passed through previous sorting steps. In Section 5, we mentioned that as little as $50 \mathrm{ppm}$ of PVC could contaminate an entire load of PET plastics; thus, further sorting can be necessary after whole plastic items are flaked. Flake sorters separate plastics down to $1 \mathrm{~mm}$ in size, depending on equipment types. Table 5 reports the currently available plastic flake sorters. Thirty-five flake sorters, manufactured by 16 companies, have been identified. This compares to 25 sorters identified in the 20114 R Sustainability report. The reported accuracy that flake sorters can attain is $99 \%$, depending on material inputs. Identification of plastic type is achieved using NIR, XRF, or VIS. Seventeen flake sorters have the ability to sort flakes by color. 


\subsection{AI-based Sorting Robots}

In order to tackle challenges encountered in the field of waste management, new approaches are being developed based on the use of computers and robotic technologies (Figure 4) [16,45]. Sorting robots, guided by AI, can either operate as an alternative to traditional optical sorters or can supplement optical sorters by purging incorrectly sorted plastics at the end of the sorting process [16]. Moreover, AI sorters have the ability to improve sorting efficiency over time by using available data to mimic a human brain's learning and decision-making processes [46-48].
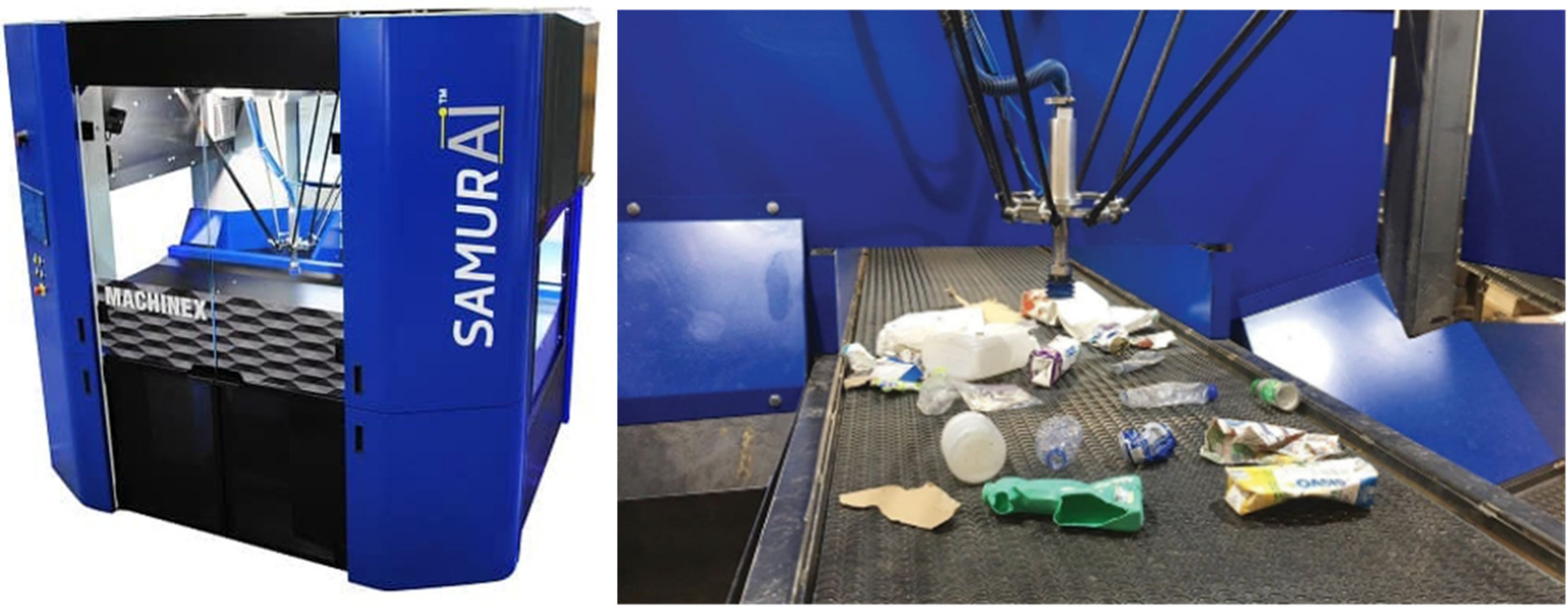

Figure 4. AI-based sorting robots, extracted from: https: / www.machinexrecycling.com/products / samurai-sorting-robot/ (last accessed on 12 February 2022).

A total of seven AI-based sorters are reported here from seven different companies, all with the ability to sort plastic by type and color (Table 6). Some MRFs have already integrated AI-based sorters in their processing line, according to manufacturers of AIbased sorters that report in their publicity materials lists of MRFs that have adopted their technologies. The plastic identification method or sorting method involves Deep Learning and VIS, and in some cases, combine Deep Learning, VIS, and NIR. Past reports (4R Sustainability [19] and Delavelle [20]) did not report any AI-based sorters. 
Table 3. Inventory of commercially available sorters for whole (i.e., bottle) plastic.

\begin{tabular}{|c|c|c|c|c|c|c|c|c|c|c|}
\hline Manufacturer/Brand & Equipment Name & Sorting Method & Primary Application & Plastic Identified & $\begin{array}{l}\text { Sorts Non-Bottle } \\
\text { Rigids in } \\
\text { Addition to Bottle }\end{array}$ & Non-Plastics Sorted & $\begin{array}{c}\text { Colors } \\
\text { Sorted/Black } \\
\text { Plastic Sorted } \\
\end{array}$ & $\begin{array}{l}\text { Throughput } \\
\text { (Average) }\end{array}$ & Accuracy & Features \\
\hline \multirow[t]{2}{*}{ Binder + Co } & Clarity Plastic & $\begin{array}{l}\text { NIR, Reflection } \\
\text { VIS, Inductive } \\
\text { metal detection }\end{array}$ & $\begin{array}{c}\text { Light weight } \\
\text { packaging, film sorting, } \\
\text { plastic flakes, } \\
\text { plastic granules, and } \\
\text { hallow plastic sorting }\end{array}$ & & & & Yes/_ & $\begin{array}{l}0.5 \text { tons per hour } \\
\text { (t/h) for } 700 \mathrm{~mm} \\
\text { sorting width, } \\
0.7 \mathrm{t} / \mathrm{h} \text { for } \\
100 \mathrm{~mm} \text {, and } 1 \mathrm{t} / \mathrm{h} \\
\text { for } 1400 \mathrm{~mm}\end{array}$ & & Metal detection \\
\hline & $\begin{array}{c}\text { Clarity Multiway } \\
\text { Light Weight }\end{array}$ & NIR & & PET, PE, PP, PVC & & Paper and cardboard & - & 2.4-3.5 ton/hour & & \\
\hline \multirow{6}{*}{$\begin{array}{l}\text { CP Group (MSS) } \\
\text { sorting equipment }\end{array}$} & $\begin{array}{l}\text { MSS CIRRUS } \\
\text { PlasticMax }\end{array}$ & $\begin{array}{l}\text { High-resolution } \\
\text { NIR/color sensor }\end{array}$ & Sorts all resins & $\begin{array}{l}\text { PET, PE, PVC, } \\
\text { HDPE, PP, PS, } \\
\text { PLA, PET-G, etc. }\end{array}$ & Yes & Yes & _/Yes & $\begin{array}{c}600-800 \\
\text { picks/minute }\end{array}$ & Up to $98 \%$ & $\begin{array}{l}\text { Identifies and } \\
\text { recovers the most } \\
\text { challenging } \\
\text { materials, such as } \\
\text { short fills, labels, } \\
\text { and PET-G }\end{array}$ \\
\hline & $\begin{array}{l}\text { Sapphire_Plastic } \\
\text { Sorting } \\
\text { Equipment }\end{array}$ & NIR & $\begin{array}{l}\text { To extract mixed } \\
\text { plastic resins from } \\
\text { low-grade material }\end{array}$ & & & Paper, cartons & & & $95 \%$ to $98 \%$ & $\begin{array}{l}\text { Single eject or } \\
\text { dual eject setup }\end{array}$ \\
\hline & MSS Aladdin & NIR and Vis & PET and HDPE & All resins & Yes & Yes & Yes/Yes & $\begin{array}{l}\text { Up to } 6 \text { ton/hour } \\
\text { for plastic } \\
\text { bottles/containers }\end{array}$ & $92-98 \%$ & $\begin{array}{l}\text { All metal detector, } \\
\text { split machine }\end{array}$ \\
\hline & MSS Sapphire & NIR & PET and HDPE & All resins & Yes & & No/_ & $\begin{array}{l}\text { Up to } 6 \text { ton/hour } \\
\text { for plastic } \\
\text { bottles/containers }\end{array}$ & $92-98 \%$ & $\begin{array}{l}\text { All metal detector, } \\
\text { split machine }\end{array}$ \\
\hline & FlakeMax & & $\begin{array}{l}\text { Best suited for PET and } \\
\text { PE/PP }\end{array}$ & & Non-metals & & $-{ }_{-}$ & 3-16 ton/hour & Up to $98 \%$ & \\
\hline & PurePlasticMax & $\begin{array}{l}\text { NIR and color } \\
\text { spectrometry with } \\
\text { optional metal } \\
\text { detection }\end{array}$ & $\begin{array}{l}\text { Sorts even the most } \\
\text { challenging plastics }\end{array}$ & $\begin{array}{l}\text { Full-body sleeved } \\
\text { PET, PE, and PP } \\
\text { bottles }\end{array}$ & Metals & & Yes/Yes & & Up to $98 \%$ & \\
\hline
\end{tabular}


Table 3. Cont.

\begin{tabular}{|c|c|c|c|c|c|c|c|c|c|c|}
\hline Manufacturer/Brand & Equipment Name & Sorting Method & Primary Application & Plastic Identified & $\begin{array}{l}\text { Sorts Non-Bottle } \\
\text { Rigids in } \\
\text { Addition to Bottle }\end{array}$ & Non-Plastics Sorted & $\begin{array}{c}\text { Colors } \\
\text { Sorted/Black } \\
\text { Plastic Sorted }\end{array}$ & $\begin{array}{c}\text { Throughput } \\
\text { (Average) }\end{array}$ & Accuracy & Features \\
\hline Eagle Vizion & Aquila Series & NIR & $\begin{array}{l}\text { Pure Streams of HDPE } \\
\text { and PET }\end{array}$ & $\begin{array}{l}\text { HDPE (color vs. } \\
\text { natural), PP, PET, } \\
\text { PS, PVC, Tetra, } \\
\text { PLA, etc. }\end{array}$ & & - & Yes/Yes & & $90 \%$ & $\begin{array}{l}\text { Can be combined } \\
\text { with several belts }\end{array}$ \\
\hline $\begin{array}{c}\text { Everyready } \\
\text { Manufacturing }\end{array}$ & NIRsort & & & & & & & $\begin{array}{l}\text { Up to } 2.5 \\
\text { ton/hour }\end{array}$ & & \\
\hline \multirow[t]{2}{*}{$\begin{array}{l}\text { Green Machine } \\
\text { LLC }\end{array}$} & $\begin{array}{c}\text { Green Eye } \\
\text { Hyperspectral } \\
\text { Robotic Sorters }\end{array}$ & Patent Pending & Sorts all plastics & $\begin{array}{l}\text { Identification of } \\
\text { all grades of } \\
\text { plastics }\end{array}$ & & & _/Yes & $\begin{array}{l}6 \text { ton } / \text { hour } \\
\left(60^{\prime \prime} \text { belt width }\right)\end{array}$ & $\begin{array}{l}95 \% \text { or } \\
\text { more }\end{array}$ & $\begin{array}{c}\text { Can be trained to } \\
\text { identify and pick } \\
\text { out almost any } \\
\text { type of polymer } \\
\text { by shape, and } \\
\text { chemical } \\
\text { composition }\end{array}$ \\
\hline & $\begin{array}{l}\text { Green Eye Optical } \\
\text { Sorter }\end{array}$ & $\begin{array}{l}\text { Neural network } \\
\text { AI-driven } \\
\text { software/NIR }\end{array}$ & Sorts all resins & Sorts all resins & & & Yes & Up to 10 ton/hour & $\begin{array}{l}95 \% \text { or } \\
\text { better } \\
\text { accuracy } \\
\text { rate }\end{array}$ & \\
\hline IMRO & $\begin{array}{c}\text { Model DSS- } \\
\text { Sensor-Based } \\
\text { Sorting Separators }\end{array}$ & $\begin{array}{l}\text { NIR, color camera, } \\
\text { metal sensor, } 3 \mathrm{D} \\
\text { camera }\end{array}$ & Sorts all resins & Sorts all resins & Yes & & Yes/Yes & & Up to $98 \%$ & \\
\hline \multirow{6}{*}{$\begin{array}{l}\text { RTT Steinert } \\
\text { GmbH) }\end{array}$} & Unisort & NIR & Sort mixed containers & $\begin{array}{c}\text { PET, HDPE, PP, } \\
\text { PS, PVC, } \\
\text { TETRAPAK }\end{array}$ & & & No/_ & $\begin{array}{l}\text { Depends on } \\
\text { conveyor's width }\end{array}$ & $\begin{array}{l}90 \% \text { or } \\
\text { better }\end{array}$ & \\
\hline & Unisort PX & NIR & Sort mixed containers & $\begin{array}{c}\text { PET, HDPE, PP, } \\
\text { PS, PVC, } \\
\text { TETRAPAK }\end{array}$ & & & No/_ & $\begin{array}{l}\text { Depends on } \\
\text { conveyor's width }\end{array}$ & $\begin{array}{l}90 \% \text { or } \\
\text { better }\end{array}$ & \\
\hline & Unisort Multi5 & NIR & Sort mixed containers & $\begin{array}{l}\text { PET, HDPE, PP, } \\
\text { PS, PVC, and } \\
\text { others }\end{array}$ & & & Yes & & $80-98 \%$ & \\
\hline & Unisort RDF & NIR & Sorts PVC & PVC & & & No & & $90 \%$ & \\
\hline & Unisort Black & & $\begin{array}{l}\text { Separates dark and } \\
\text { unknown objects that } \\
\text { would otherwise } \\
\text { become lost }\end{array}$ & & & & Yes/Yes & & & \\
\hline & Unisort C & $\begin{array}{l}\text { Color sensors } \\
\text { (Linear cameras) }\end{array}$ & $\begin{array}{l}\text { Separate PET bottles by } \\
\text { color }\end{array}$ & & & & Yes/ & $\begin{array}{l}1.5-4 \text { ton/hour, } \\
\text { depending on } \\
\text { sorting width of } \\
\text { conveyor }\end{array}$ & $97 \%$ & \\
\hline
\end{tabular}


Table 3. Cont.

\begin{tabular}{|c|c|c|c|c|c|c|c|c|c|c|}
\hline Manufacturer/Brand & Equipment Name & Sorting Method & Primary Application & Plastic Identified & $\begin{array}{c}\text { Sorts Non-Bottle } \\
\text { Rigids in } \\
\text { Addition to Bottle }\end{array}$ & Non-Plastics Sorted & $\begin{array}{c}\text { Colors } \\
\text { Sorted/Black } \\
\text { Plastic Sorted } \\
\end{array}$ & $\begin{array}{l}\text { Throughput } \\
\text { (Average) }\end{array}$ & Accuracy & Features \\
\hline \multirow{4}{*}{ NRT } & MultiSort ES & Vision-based & $\begin{array}{l}\text { Frequently used for } \\
\text { color sorting PET } \\
\text { bottles }\end{array}$ & None & Yes & & Yes/Yes & 5.5 ton/hour & $95 \%$ & Metal detector \\
\hline & MultiSort IR & NIR & & & Yes & & No/No & 5.5 ton/hour & $99 \%$ & Metal detector \\
\hline & VinylCycle & X-ray & Sorts PVC & & & & & & & \\
\hline & SpydIR-R & NIR & $\begin{array}{l}\text { Sort polymers from } \\
\text { mixed stream }\end{array}$ & $\begin{array}{l}\text { PVC, PS, PETG, } \\
\text { PLA, PC, PE, PP, } \\
\text { and other }\end{array}$ & Yes & $\begin{array}{l}\text { Cardboard, paper, } \\
\text { and fiber }\end{array}$ & No/No & 5.5 ton/hour & & $\begin{array}{l}\text { Uses PET boost } \\
\text { that improves } \\
\text { detection of } \\
\text { thin-wall PET, wet } \\
\text { PET, and } \\
\text { full-sleeve labeled } \\
\text { PET } \\
\end{array}$ \\
\hline \multirow{4}{*}{ Pellenc ST } & Mistral & NIR & $\begin{array}{l}\text { Mainly used to sort } \\
\text { PET and HDPE }\end{array}$ & Sorts all resins & Yes & & No/No & 6.5 ton/hour & $\begin{array}{l}<50 \mathrm{ppm} \text { of } \\
\text { PVC and } \\
\text { metal con- } \\
\text { taminants }\end{array}$ & $\begin{array}{l}\text { Metal detector } \\
\text { unit }\end{array}$ \\
\hline & Mistral+ Connect & $\begin{array}{l}\text { NIR/VIS } \\
\text { spectrum }\end{array}$ & $\begin{array}{c}\text { provides better } \\
\text { detection and sorting } \\
\text { PET bottles versus PET } \\
\text { trays or thermoforms, } \\
\text { paper versus } \\
\text { cardboard in sorting } \\
\text { centres }\end{array}$ & $\begin{array}{l}\text { PET, PE, PP, paper, } \\
\text { films, wood, } \\
\text { domestic waste, } \\
\text { organic, RDF... }\end{array}$ & & & - / Yes & & & \\
\hline & Siroco & Vision Technology & $\begin{array}{l}\text { Color sort for PET od } \\
\text { HDPE }\end{array}$ & NA & & $\begin{array}{l}\text { No/PET: Tri-sort } \\
\text { into clear, green, and } \\
\text { other (blue or mixed } \\
\text { crystal }\end{array}$ & & 6.5 ton/hour & & $\begin{array}{l}\text { Metal detector } \\
\text { unit }\end{array}$ \\
\hline & Bi-Techno & $\begin{array}{l}\text { NIR and Vision } \\
\text { technology } \\
\text { (color) }\end{array}$ & Pure Stream of PET & $\begin{array}{l}\text { PET, PVC, PS, EPS, } \\
\text { HDPE, } \\
\text { Beverage carton, } \\
\text { PP, PE, PLA }\end{array}$ & & $\begin{array}{l}\text { _/PET: Tri-sort into } \\
\text { clear, green, and } \\
\text { “other “OR blue, } \\
\text { mixed, crystal } \\
\text { HDPE: Natural and } \\
\text { colored }\end{array}$ & No/No & 6.5 ton/hour & $98 \%$ & $\begin{array}{l}\text { Metal Detector } \\
\text { Unit }\end{array}$ \\
\hline PicVisa & $\begin{array}{l}\text { Ecopack-Model } \\
\text { EP Optical Plastic } \\
\text { Sorting Machine }\end{array}$ & $\begin{array}{l}\text { NIR, VIS, Deep } \\
\text { Learning }\end{array}$ & $\begin{array}{l}\text { PET/PE recycling, } \\
\text { Plastic film } \\
\text { (PEBD, PP, } \\
\text { HDPE/LDPE, etc.) }\end{array}$ & $\begin{array}{l}\text { PET, HDPE, PP, } \\
\text { PS, PVC, EPS, } \\
\text { ABS) } \\
\text { HDPE, PET, } \\
\text { Mixed LDPE, } \\
\text { Sorting film } \\
\text { (HDPE/LDPE) }\end{array}$ & $\begin{array}{l}\text { Yes, sorting of } \\
\text { films (PE) from } \\
\text { bottles of the same } \\
\text { material }\end{array}$ & $\begin{array}{l}\text { Paper, and } \\
\text { cardboards, Wood } \\
\text { recycling, Metal } \\
\text { recycling }\end{array}$ & Yes/_ & & & $\begin{array}{c}\text { Allows separating } \\
\text { the always-present } \\
\text { silicone cartridges } \\
\text { in HDPE flows }\end{array}$ \\
\hline
\end{tabular}


Table 3. Cont.

\begin{tabular}{|c|c|c|c|c|c|c|c|c|c|c|}
\hline Manufacturer/Brand & Equipment Name & Sorting Method & Primary Application & Plastic Identified & $\begin{array}{l}\text { Sorts Non-Bottle } \\
\text { Rigids in } \\
\text { Addition to Bottle }\end{array}$ & Non-Plastics Sorted & $\begin{array}{c}\text { Colors } \\
\text { Sorted/Black } \\
\text { Plastic Sorted } \\
\end{array}$ & $\begin{array}{l}\text { Throughput } \\
\text { (Average) }\end{array}$ & Accuracy & Features \\
\hline \multirow{3}{*}{$\begin{array}{l}\text { BT-Wolfgang } \\
\text { Binder GmbH } \\
\text { (Redwave) }\end{array}$} & Redwave NIR/C & NIR & $\begin{array}{c}\text { Bottles (PET, HDPE, } \\
\text { PP), films, } \\
\text { bio-degradable plastics }\end{array}$ & $\begin{array}{c}\text { PET, PE, PP, PS, } \\
\text { PVC, ABS, PC, PC, } \\
\text { POM, PU (and all } \\
\text { other non-black } \\
\text { plastics) }\end{array}$ & & $\begin{array}{l}\text { Electric scrap, Refuse } \\
\text { Derived Fuel (RDF), } \\
\text { Demolition waste/ }\end{array}$ & Yes/No & $\begin{array}{c}8 \text { ton/hour } \\
\text { (depending on the } \\
\text { material and task) }\end{array}$ & $\begin{array}{l}\text { Up to } 99 \% \text {, } \\
\text { depending } \\
\text { on the } \\
\text { input } \\
\text { material }\end{array}$ & $\begin{array}{c}\text { Metals and alloys, } \\
\text { glass, and other } \\
\text { materials. } \\
\text { Elimination of } \\
\text { brominated } \\
\text { plastics (BFR), } \\
\text { plastics with } \\
\text { cadmium } \\
\text { compounds }\end{array}$ \\
\hline & Redwave XRF-P & X-ray Fluorescent & $\begin{array}{l}\text { Segregation of dark } \\
\text { PVC and brominated } \\
\text { plastics from an infeed } \\
\text { of shredded plastics }\end{array}$ & $\begin{array}{l}\text { BFR and chloride } \\
\text { containing plastics }\end{array}$ & & & No/No & & $\begin{array}{l}\text { Up to } 99 \% \text {, } \\
\text { depending } \\
\text { on input } \\
\text { material }\end{array}$ & \\
\hline & $\begin{array}{l}\text { Redwave } \\
\text { NIR-SSI/C }\end{array}$ & $\begin{array}{l}\text { NIR spectroscopy } \\
\text { combined with } \\
\text { Color detection }\end{array}$ & Fine material sorting & $\begin{array}{c}\text { Flakes, medical } \\
\text { waste, e-scrap, } \\
\text { PVC separation at } \\
\text { pulper reject and } \\
\text { RDF } \\
\end{array}$ & & -1 & No/_ & $2.5-4.0$ ton/hour & $80-98 \%$ & \\
\hline Rofin & Rapid Sort 75 & NIR & All resins & $\begin{array}{l}\text { PET, PE, PVC, PP, } \\
\text { PS, and others }\end{array}$ & Yes & & _Yes & & $99 \%$ & \\
\hline \multirow{3}{*}{$\begin{array}{c}\text { Sesotec GmbH } \\
\text { (S+S Separation } \\
\text { and Sorting } \\
\text { Technology } \\
\text { GmbH) }\end{array}$} & Varisort CS-P & $\begin{array}{c}\text { CCD Linear } \\
\text { camera }\end{array}$ & Sorts plastic by color & & Yes & & No/No & & & \\
\hline & Varisort NS-P & NIR & Sorts all resins & Sorts all resin & & & Yes/Yes & $\begin{array}{l}\text { Up to } 10 \text { ton/hour } \\
\text { depending on } \\
\text { scale }\end{array}$ & $\begin{array}{c}90 \% \text { to } \\
99.8 \% \\
\text { depending } \\
\text { on input } \\
\end{array}$ & \\
\hline & Varisort X & X-ray & $\begin{array}{l}\text { Mainly used to sort } \\
\text { BFR containing plastics }\end{array}$ & & & & No/No & $\begin{array}{l}\text { Up to } 10 \text { ton/hour } \\
\text { depending on } \\
\text { scale }\end{array}$ & $\begin{array}{c}90 \% \text { to } \\
99.8 \% \\
\text { depending } \\
\text { on material } \\
\text { input }\end{array}$ & \\
\hline
\end{tabular}


Table 3. Cont.

\begin{tabular}{|c|c|c|c|c|c|c|c|c|c|c|}
\hline Manufacturer/Brand & Equipment Name & Sorting Method & Primary Application & Plastic Identified & $\begin{array}{l}\text { Sorts Non-Bottle } \\
\text { Rigids in } \\
\text { Addition to Bottle }\end{array}$ & Non-Plastics Sorted & $\begin{array}{c}\text { Colors } \\
\text { Sorted/Black } \\
\text { Plastic Sorted }\end{array}$ & $\begin{array}{l}\text { Throughput } \\
\text { (Average) }\end{array}$ & Accuracy & Features \\
\hline Titech GmbH & Autosort & $\begin{array}{c}\text { NIR and } \\
\text { spectroscopy color } \\
\text { detection (also } \\
\text { available in just } \\
\text { NIR) }\end{array}$ & & $\begin{array}{c}\text { PET, PETG, HDPE, } \\
\text { LDPE, PP, PVC, } \\
\text { PLA, PS, HIPS, } \\
\text { ABS, PC, PC-ABS, } \\
\text { POM, PA, PPO, } \\
\text { PMMA }\end{array}$ & Yes & - & Yes/Yes & 10 ton $/$ hour & $\begin{array}{l}99.99 \% \\
\text { when using } \\
\text { multiple } \\
\text { machines }\end{array}$ & \\
\hline \multirow{2}{*}{$\begin{array}{l}\text { TOMRA systems } \\
\text { ASA }\end{array}$} & Autosort & NIR, Visual & $\begin{array}{l}\text { Mixed packaging } \\
\text { waste, RDF, Sorting } \\
\text { paper, PET/PE } \\
\text { recycling }\end{array}$ & $\begin{array}{l}\text { Sorting of e. g. } \\
\text { beverage cartons, } \\
\text { PE, PP, PS, PVC, } \\
\text { PET, EPS, ABS by } \\
\text { type of material }\end{array}$ & $\begin{array}{c}\text { Removing all } \\
\text { metals }\end{array}$ & & Yes/Yes & & & Remote Access \\
\hline & Autosort Laser & NIR, laser & $\begin{array}{l}\text { Mainly used for glass } \\
\text { sorting. However, has } \\
\text { the ability to sort } \\
\text { plastics as well }\end{array}$ & & & & No/No & & & \\
\hline $\begin{array}{l}\text { Unisensor } \\
\text { Sensorsysteme } \\
\text { GmbH }\end{array}$ & Powersort 200 & laser spectroscopy & Sorts all resins & & Yes & & Yes/Yes & & Up to $98 \%$ & \\
\hline \multirow[t]{2}{*}{ Visys } & Cayman & NIR & $\begin{array}{l}\text { Used to obtain resin } \\
\text { streams }\end{array}$ & $\begin{array}{l}\text { PET, HDLPE, PP, } \\
\text { PS, PE, PVC and } \\
\text { others }\end{array}$ & Yes & & No/No & $\begin{array}{l}5 \text { ton/hour } \\
\text { depending on the } \\
\text { input material }\end{array}$ & $\begin{array}{l}\text { Up to } 99 \% \\
\text { depending } \\
\text { on input } \\
\text { materials }\end{array}$ & \\
\hline & NIREX & $\begin{array}{l}\text { NIR and vision } \\
\text { technology }\end{array}$ & $\begin{array}{l}\text { Used to obtain resin } \\
\text { streams }\end{array}$ & $\begin{array}{l}\text { PET, HDPE, PE, } \\
\text { PP, PVC, and } \\
\text { others }\end{array}$ & Yes & & Yes/Yes & 4 ton/hour & $\begin{array}{l}\text { Depends } \\
\text { on product } \\
\text { type }\end{array}$ & $\begin{array}{c}\text { Can be combined } \\
\text { with other sorting } \\
\text { units }\end{array}$ \\
\hline
\end{tabular}


Table 4. Inventory of commercially available film sorters.

\begin{tabular}{|c|c|c|c|c|c|c|c|c|c|c|}
\hline Manufacturer/Brand & Equipment Name & Sorting Method & Primary Application & Plastic Identified & $\begin{array}{l}\text { Sorts Non-Bottle } \\
\quad \text { Rigids in } \\
\text { Addition to Bottle }\end{array}$ & $\begin{array}{l}\text { Non-Plastics } \\
\text { Sorted }\end{array}$ & $\begin{array}{c}\text { Colors } \\
\text { Sorted/Black } \\
\text { Plastic Sorted }\end{array}$ & $\begin{array}{c}\text { Throughput } \\
\text { (Average) }\end{array}$ & Accuracy & Features \\
\hline Amut Ecotech & $\begin{array}{c}\text { Machina Cattura } \\
\text { Sacchetti Film } \\
\text { graber Machine } \\
\text { Unit }\end{array}$ & $\begin{array}{l}\text { high efficiency } \\
\text { blower fan }\end{array}$ & $\begin{array}{l}\text { Sorts films and plastic } \\
\text { bags }\end{array}$ & & & & & & & \\
\hline Binder + Co & Clarity Plastic & $\begin{array}{l}\text { NIR, Reflection } \\
\text { VIS, Inductive } \\
\text { metal detection }\end{array}$ & $\begin{array}{l}\text { Lightweight packaging, } \\
\text { film sorting, plastic } \\
\text { flakes, plastic granules, } \\
\text { and hallow plastic } \\
\text { sorting }\end{array}$ & & & & Yes/_ & $\begin{array}{c}0.5 \text { ton/hour for } \\
700 \mathrm{~mm} \text { sorting } \\
\text { width, } \\
0.7 \text { ton/hour for } \\
100 \mathrm{~mm} \text {, and } \\
1 \text { ton } / \text { hour for } \\
1400 \mathrm{~mm}\end{array}$ & & Metal detection \\
\hline $\begin{array}{c}\text { CP Group (MMS) } \\
\text { Sorting } \\
\text { Equipment }\end{array}$ & FilmMax & $\begin{array}{l}\text { NIR, color, and } \\
\text { metal sensors }\end{array}$ & $\begin{array}{l}\text { Sorts bags, pouches, } \\
\text { foil, and other } \\
\text { ultra-light products }\end{array}$ & $\begin{array}{l}\text { LDPE/LLDPE } \\
\text { films, PET, PVC, } \\
\text { PS }\end{array}$ & Non-metals & & - /_ & $0.5-3.0$ ton/hour & Up to $98 \%$ & \\
\hline $\begin{array}{l}\text { RTT Steinert } \\
\text { GmbH }\end{array}$ & Unisort Film & NIR, VIS & $\begin{array}{l}\text { Agricultural Film, } \\
\text { Bio-based Film, } \\
\text { Biodegradable Film, } \\
\text { Conventional PVC } \\
\text { Film and papers }\end{array}$ & $\begin{array}{l}\text { Plastic film, bags, } \\
\text { and paper }\end{array}$ & & & Yes/ & & & \\
\hline \multirow[b]{2}{*}{ Pellenc ST } & Mistral + Films & NIR & $\begin{array}{l}\text { Used to separate films } \\
\text { from other plastics }\end{array}$ & PE film & & $\begin{array}{c}\text { Papers, } \\
\text { cardboards, and } \\
\text { metals/No }\end{array}$ & No/No & $\begin{array}{l}\text { Up to } 2.5 \\
\text { ton/hour }\end{array}$ & Up to $91 \%$ & \\
\hline & Mistral+ Connect & $\begin{array}{l}\text { NIR/VIS } \\
\text { spectrum }\end{array}$ & $\begin{array}{c}\text { provides better } \\
\text { detection and sorting } \\
\text { PET bottles versus PET } \\
\text { trays or thermoforms, } \\
\text { paper versus } \\
\text { cardboard in sorting } \\
\text { centres }\end{array}$ & $\begin{array}{l}\text { PET, PE, PP, paper, } \\
\text { films, wood, } \\
\text { domestic waste, } \\
\text { organic, RDF... }\end{array}$ & & & $-/$ Yes & & & \\
\hline PicVisa & $\begin{array}{l}\text { Ecopack-Model } \\
\text { EP Optical Plastic } \\
\text { Sorting Machine }\end{array}$ & $\begin{array}{l}\text { NIR, VIS, Deep } \\
\text { Learning }\end{array}$ & $\begin{array}{l}\text { PET/PE recycling, } \\
\text { Plastic film } \\
\text { (PEBD, PP, } \\
\text { HDPE/LDPE ... ) }\end{array}$ & $\begin{array}{c}\text { PET, HDPE, PP, } \\
\text { PS, PVC, EPS, } \\
\text { ABS) } \\
\text { LDPE, film } \\
\text { (HDPE/LDPE) }\end{array}$ & $\begin{array}{l}\text { Yes, sorting of } \\
\text { films (PE) from } \\
\text { bottles of the same } \\
\text { material }\end{array}$ & $\begin{array}{l}\text { Paper, and } \\
\text { cardboard, Wood } \\
\text { recycling, Metal } \\
\text { recycling }\end{array}$ & Yes/_ & & & $\begin{array}{c}\text { Allows separating } \\
\text { the always-present } \\
\text { silicone cartridges } \\
\text { in HDPE flows }\end{array}$ \\
\hline Steinert $\mathrm{GmbH}$ & Unisort Film & NIR, VIS & $\begin{array}{l}\text { Agricultural Film, } \\
\text { Bio-based Film, } \\
\text { Biodegradable Film, } \\
\text { Conventional PVC } \\
\text { Film and papers }\end{array}$ & $\begin{array}{l}\text { Plastic film, bags, } \\
\text { and paper }\end{array}$ & & Yes/_ & & & & \\
\hline $\begin{array}{c}\text { TOMRA systems } \\
\text { ASA }\end{array}$ & Autosort Speedair & & & $\begin{array}{l}\text { Film (LDPE, } \\
\text { HDPE), papers, } \\
\text { and packaging }\end{array}$ & & & & & & \\
\hline
\end{tabular}


Table 5. Inventory of commercially available flake sorters.

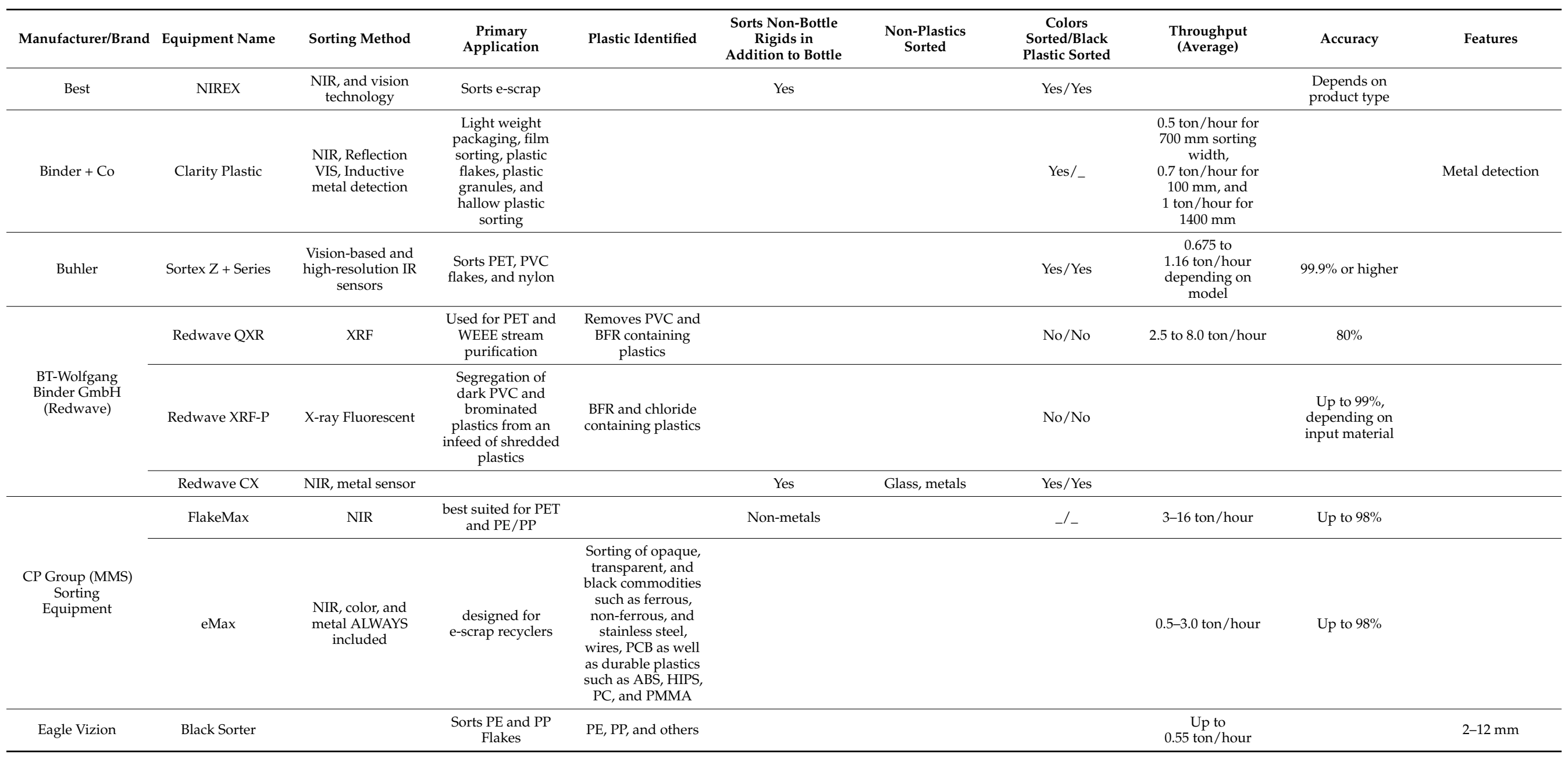


Table 5. Cont.

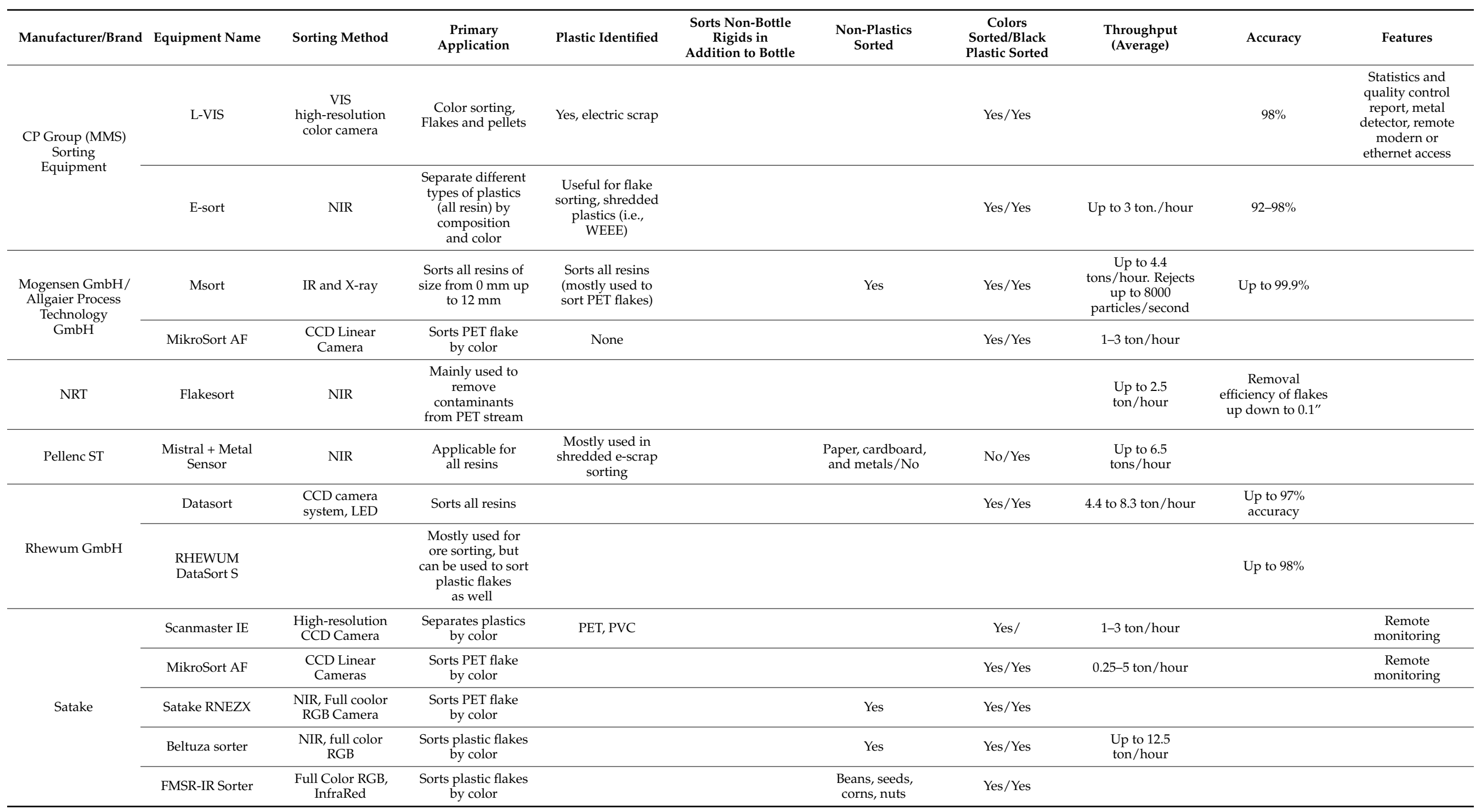


Table 5. Cont.

\begin{tabular}{|c|c|c|c|c|c|c|c|c|c|c|}
\hline Manufacturer/Brand & Equipment Name & Sorting Method & $\begin{array}{c}\text { Primary } \\
\text { Application }\end{array}$ & Plastic Identified & $\begin{array}{l}\text { Sorts Non-Bottle } \\
\text { Rigids in } \\
\text { Addition to Bottle }\end{array}$ & $\begin{array}{c}\text { Non-Plastics } \\
\text { Sorted }\end{array}$ & $\begin{array}{c}\text { Colors } \\
\text { Sorted/Black } \\
\text { Plastic Sorted }\end{array}$ & $\begin{array}{c}\text { Throughput } \\
\text { (Average) }\end{array}$ & Accuracy & Features \\
\hline \multirow{3}{*}{ Satake } & ScanMaster XE & $\begin{array}{c}\text { Proprietary } \\
\text { inGas/Color } \\
\text { camera } \\
\text { technology }\end{array}$ & $\begin{array}{l}\text { Remove clear PVC } \\
\text { from PET, and } \\
\text { other } \\
\text { non-contaminants }\end{array}$ & Sorts all resin & & Yes & No/No & Up to 3lton/hour & & $\begin{array}{c}\text { Remote } \\
\text { monitoring }\end{array}$ \\
\hline & $\begin{array}{l}\text { RGB Full Color } \\
\text { Belt Sorter }\end{array}$ & $\begin{array}{l}\text { NIR, Full color } \\
\text { Cameras (RGB) }\end{array}$ & $\begin{array}{l}\text { Separates plastics } \\
\text { by color }\end{array}$ & PET, Toasted PVC & & & Yes/Yes & 9 to $19 \mathrm{t} / \mathrm{h}$ & Up to $99 \%$ & \\
\hline & Pellet Scan & $\begin{array}{l}\text { High-resolution } \\
\text { CCD Cameras }\end{array}$ & $\begin{array}{l}\text { Separates plastics } \\
\text { by color }\end{array}$ & No & & & & & Up to $99 \%$ & Data Scan \\
\hline \multirow{2}{*}{$\begin{array}{c}\text { Sesotec GmbH } \\
\text { (S+S Separation } \\
\text { and Sorting } \\
\text { Technology } \\
\text { GmbH) }\end{array}$} & Flake Purifier C & $\begin{array}{l}\text { CCD linear } \\
\text { camera }\end{array}$ & Color sorting & No & & & Yes/Yes & $\begin{array}{l}\text { Up to } 10 \text { ton/hour } \\
\text { depending on how } \\
\text { the unit is scaled }\end{array}$ & $\begin{array}{c}90 \% \text { to } 99.8 \% \\
\text { depending on } \\
\text { input }\end{array}$ & Dual Ejection \\
\hline & Varisort X & X-ray & $\begin{array}{c}\text { Identifies BFR } \\
\text { containing plastics }\end{array}$ & $\begin{array}{l}\text { Identifies BFR } \\
\text { containing plastics }\end{array}$ & & & No/No & $\begin{array}{c}\text { Up to } 2.5 \\
\text { ton/hour } \\
\text { depending on how } \\
\text { the unit is scaled }\end{array}$ & & Dual Ejection \\
\hline \multirow{3}{*}{$\begin{array}{c}\text { TOMRA Systems } \\
\text { ASA }\end{array}$} & Ixus & X-ray & $\begin{array}{l}\text { Useful for sorting } \\
\text { shredded e-scrap }\end{array}$ & $\begin{array}{c}\text { Useful for sorting } \\
\text { BFR and chloride } \\
\text { containing plastics } \\
\text { (i.e., PVC) }\end{array}$ & & & No/No & 1 ton/hour & $\begin{array}{l}\text { Depends on } \\
\text { product type }\end{array}$ & \\
\hline & Innosort Flake & $\begin{array}{l}\text { NIR, Visible } \\
\text { spectra } \\
\text { Sensors }\end{array}$ & $\begin{array}{l}\text { Used for purifying } \\
\text { PET flakes, } \\
\text { purifying } \\
\text { transparent and } \\
\text { opaque flakes, } \\
\text { sorting of mixed } \\
\text { color flakes }\end{array}$ & $\begin{array}{l}\text { PVC, PE, PET, PP, } \\
\text { PS, and others, } \\
\text { including } \\
\text { Tetrapak and film }\end{array}$ & & & Yes/_ & & & \\
\hline & Autosort Flake & $\begin{array}{l}\text { Flying beam, } \\
\text { full-color camera }\end{array}$ & $\begin{array}{l}\text { Sorts plastic } \\
\text { Flakes }\end{array}$ & & & & & & & \\
\hline $\begin{array}{c}\text { Unisensor } \\
\text { Sensorsysteme } \\
\text { GmbH }\end{array}$ & PowerSort 200 & $\begin{array}{l}\text { Ultra-high-speed } \\
\text { Lase Spectroscopy }\end{array}$ & $\begin{array}{c}\text { Useful for } \\
\text { bottle-to-bottle } \\
\text { recycling }\end{array}$ & Sorts all resins & & & Yes/Yes & Up to 3 ton/hour & $98 \%$ or higher & \\
\hline Visys & Spyder & Laser & $\begin{array}{c}\text { Separation based } \\
\text { on color, structure, } \\
\text { shape and size } \\
\text { differences }\end{array}$ & No & & & Yes/Yes & $1-3$ ton $/$ hour & $\begin{array}{l}\text { Up to } 99 \% \\
\text { depending on } \\
\text { input }\end{array}$ & \\
\hline
\end{tabular}


Table 5. Cont.

\begin{tabular}{|c|c|c|c|c|c|c|c|c|c|c|}
\hline Manufacturer/Brand & Equipment Name & Sorting Method & $\begin{array}{c}\text { Primary } \\
\text { Application }\end{array}$ & Plastic Identified & $\begin{array}{l}\text { Sorts Non-Bottle } \\
\text { Rigids in } \\
\text { Addition to Bottle }\end{array}$ & $\begin{array}{c}\text { Non-Plastics } \\
\text { Sorted }\end{array}$ & $\begin{array}{c}\text { Colors } \\
\text { Sorted/Black } \\
\text { Plastic Sorted } \\
\end{array}$ & $\begin{array}{c}\text { Throughput } \\
\text { (Average) }\end{array}$ & Accuracy & Features \\
\hline \multirow{2}{*}{ Visys } & Python & Laser and cameras & $\begin{array}{c}\text { Separation based } \\
\text { on color, structure, } \\
\text { shape and size } \\
\text { differences }\end{array}$ & & & & & & & \\
\hline & Tyrex & X-ray & $\begin{array}{c}\text { Separation based } \\
\text { on density of } \\
\text { materials (i.e., } \\
\text { plastic, WEEE, } \\
\text { ASR) }\end{array}$ & $\begin{array}{c}\text { Useful for sorting } \\
\text { BFR and chloride } \\
\text { containing plastics } \\
\text { (i.e., PVC) }\end{array}$ & & & No/No & & $\begin{array}{l}\text { Up to } 99 \% \\
\text { depending on } \\
\text { input }\end{array}$ & \\
\hline
\end{tabular}

Table 6. Inventory of emerging AI-based sorters.

\begin{tabular}{|c|c|c|c|c|c|c|c|c|c|c|c|}
\hline $\begin{array}{c}\text { Manufacturer/ } \\
\text { Brand }\end{array}$ & Equipment Name & Sorting Method & Primary Application & Plastic Identified & $\begin{array}{c}\text { Sorts Non-Bottle } \\
\text { Rigids in Adddition to } \\
\text { Bottle }\end{array}$ & Non-Plastics Sorted & $\begin{array}{c}\text { Colors Sorted//lack } \\
\text { Plastic Sorted }\end{array}$ & Throughput (Average) & $\begin{array}{l}\text { Plants in the US Using } \\
\text { Equipment }\end{array}$ & Accuracy & Features \\
\hline AMP Robotics & Cortex & & & & Yes & Yes & -/Yes & 60 picks per minute & $\begin{array}{l}\text { Alpine Waste and } \\
\text { Recycling. Denver Co, } \\
\text { and Minnesota }\end{array}$ & $99 \%$ & $\begin{array}{l}\text { Cortex is continuously } \\
\text { learning from experience, } \\
\text { becoming better all the time }\end{array}$ \\
\hline $\begin{array}{l}\text { Back Handling Systems } \\
\text { (BHS) }\end{array}$ & Max-AI & $\begin{array}{l}\text { Deep learning } \\
\text { technology and the } \\
\text { sorting process is based } \\
\text { on the evaluation of } \\
\text { optical data } \\
\text { determined by } \\
\text { VIS-sensors }\end{array}$ & $\begin{array}{l}\text { Extract recyclable } \\
\text { commmodities from a } \\
\text { specific stram of } \\
\text { material }\end{array}$ & PET, HDPE & Yes & Yes & -/Yes & 65 picks per minute & Recology, San Francisco & & $\begin{array}{c}\text { Continuously learning to } \\
\text { improve efficiency }\end{array}$ \\
\hline $\begin{array}{l}\text { Bollegraaf Recycling } \\
\text { Solutions }\end{array}$ & $\begin{array}{c}\text { Sorting systems } \\
\text { Bollegraaf }\end{array}$ & NIR & $\begin{array}{l}\text { Sorts different types of } \\
\text { plastic, paper, } \\
\text { cardboard, cardboard } \\
\text { packaging, and Terta } \\
\text { Pak }\end{array}$ & $\begin{array}{l}\text { Sorts PS, PET, HDPE, } \\
\text { LDPE, PS, and PP to } \\
\text { Tetra Pak, cardboard or } \\
\text { paper }\end{array}$ & & & & & & & \\
\hline $\begin{array}{l}\text { BT-Wolfgang Binder } \\
\text { GmbH (Redwave) }\end{array}$ & RedWave $2 \mathrm{i}$ & $\begin{array}{l}\text { NIR, RGB cameras and } \\
\text { all-metal detectors }\end{array}$ & Sorts all resins & Sorts all resins & Yes & $\begin{array}{l}\text { Paper, metals, e-waste, } \\
\text { glass, construction } \\
\text { waste }\end{array}$ & & Up to 7 ton/hour & & & $\begin{array}{l}24 / 7 \text { remote maintenance } \\
\text { access for quick service and } \\
\text { support }\end{array}$ \\
\hline Machinex & Samur AI & $\begin{array}{l}\text { Delta robot with } \\
\text { vacuum gripper }\end{array}$ & $\begin{array}{l}\text { Extract recyclable } \\
\text { commodities from a } \\
\text { specific stream of } \\
\text { material (e.g., plastics } \\
\text { from a reject line) }\end{array}$ & $\begin{array}{l}\text { PET, colored, and } \\
\text { natural HDPE }\end{array}$ & Yes & Yes & -/Yes & $\begin{array}{l}\text { Up to } 70 \text { picks per } \\
\text { minute }\end{array}$ & $\begin{array}{l}\text { Lakeshore Recycling } \\
\text { Systems. Forest View, } \\
\text { IL }\end{array}$ & Up to $95 \%$ & $\begin{array}{l}\text { It has ongoing evolution and } \\
\text { optimization of AI material } \\
\text { recogition. II continually } \\
\text { improves and learns from } \\
\text { operating experience to } \\
\text { assure maximum recognition } \\
\text { efficiency }\end{array}$ \\
\hline OP Teknik & SELMA & Deep learning & & & & $\begin{array}{l}\text { Wood, stone, concrete, } \\
\text { bricks, metals, } \\
\text { cardiboard, foam, etc. }\end{array}$ & & & & $\begin{array}{l}300 \text { picks } / \text { min } \\
\text { (with } 6 \text { arms) or } \\
50 \text { picks } / \text { min. } \\
\text { arm }\end{array}$ & \\
\hline TOMRA Systems ASA & AutoSort CyBot & & $\begin{array}{c}\text { Packaging, beverage } \\
\text { cartons, and all } \\
\text { thermoplastics }\end{array}$ & & & & & & & & \\
\hline
\end{tabular}




\section{Conclusions}

Large volumes of plastic are generated and landfilled every year, increasing pressure to recycle them. For efficient recycling, sorting is important, as it increases the quantity and improves the quality and value of post-consumer plastics for reprocessing. As most MRFs receive large volumes of mixed plastics, automated sorting has proven efficient in separating large plastics while maintaining a high throughput of sorted materials.

This study identifies current limitations or challenges encountered by US-based MRFs when sorting plastic recyclables, reports on the types and capabilities of plastic-sorting equipment that is commercially available in North America and Europe, and assesses how the available equipment can address the sorting challenges that MRFs face. This study does not address the financial aspects of automated sorting deployment.

Findings from a survey identifying MRF needs and interviews with industry professionals indicate that MRFs struggle to sort tanglers, films, black plastics, and plastic objects made of a combination of polymers or polymer blends. Other reported challenges are that MRFs that rely heavily on manual sorting have throughput constraints. The commercial sorting equipment presented here can address some of the challenges that MRFs encounter. Black plastics can be sorted with currently available sorters (Tables 3-6). Tanglers can be partially addressed using AI-based sorters, as they have the ability to sort materials by shape and can sort wires. However, the efficiency of AI sorters in high-volume MRFs is yet to be reported. Moreover, AI-based sorters are typically placed at the end of a sorting line to remove residual or recover materials missed by optical sorters. Thus, they may not address shutdowns caused by tanglers. Throughput constraints experienced by MRFs currently utilizing manual sorting can be solved by implementing automated sorting. However, the effective sorting of multilayered, blended, or mixed-material plastics remains a challenge as sorting equipment is designed to sort single-component materials. Accordingly, new solutions or improvements are needed to improve current optical sorters to sort these complex plastics.

The inventory of commercially available sorting equipment includes 46 optical sorters for whole plastic objects, 35 flake sorters (from 16 companies), 9 film sorters (from 9 companies), and 7 AI-based sorters for mixed plastic recyclables. The previous reports were published on plastic sorting equipment date from over ten years ago $[19,20]$. The recovery efficiency of sorting equipment reported herein can be as high as $99.99 \%$, depending on input materials, with a wide range of throughput capacities (up to 10 ton $/ \mathrm{h}$ ). Growth in available sorting technology was observed ( $70 \%$ increase in whole plastic sorters, $26 \%$ increase in flake sorters) compared to the 2011 report by $4 \mathrm{R}$ Sustainability [19]. Continued growth in plastic usage and waste generation creates demand for more plastic sorters. This inventory of commercially available sorting equipment includes nine film sorters and seven AI-based sorters; past studies did not report any of these technologies, reflecting the recent advances in AI. The efficiency of film sorting at the MRF level remains low, evidenced by high contamination rates $(10 \mathrm{wt} \%)$ reported in most outgoing bales. Thus, further progress in film sorting equipment is necessary.

The sorting efficiency (91\% to 99\%) reported by MRFs in the survey is lower than that reported by equipment manufacturers (up to $99.99 \%$ ). However, a direct comparison of sorting equipment efficiency between manufacturers and MRFs was not possible, as MRFs provided little detail on the specific types of sorters in use. In practice, factors such as the composition of the incoming stream, method of sourcing, and operations at MRFs can affect the achieved sorting efficiency of optical sorters. In order to improve sorting efficiency at the MRF level, operating conditions that favor higher sorting efficiency could be required, e.g., a reduced capacity that tends to yield cleaner bales but can be financially unfavorable, or reduced heterogeneity of incoming waste, or use of sorting technologies with higher sorting efficiency.

This report reveals an improvement in the availability of sorting equipment for plastic over the past ten years, evidenced by film sorters and AI-based sorters that were not previously available. The potential efficiency of sorting equipment from past reports and 
currently available sorting equipment remains similar. This study can serve as a guide for MRFs interested in evaluating the current state of sorting equipment and identifying equipment that best matches their needs.

Perspective and Outlook: Technology for automated sorting of plastics is widely available and deployed at MRFs. Sorting technology advances will continue, with AIdriven identification and robotic manipulation being currently at the forefront. Some of the challenges in mechanical recycling that are associated with tanglers and black plastic remain to be addressed. A series of sorters specializing in different shapes or sizes of plastic would improve the sorting efficiency. Deployment of advanced technology, however, comes at a cost, and the recovery of investment depends on the market value of sorted plastic, incentives for sorting plastic and/or disincentives associated with not sorting plastic waste. Chemical recycling, if/when widely deployed, can handle plastic that currently poses challenges in mechanical recycling involving sorting. MRFs with different levels of scale and specialization, and corresponding sorting equipment, can coordinate their inputs and outputs and connect to chemical recycling plants, working toward a concerted goal to decrease the plastic that ends up in landfills and the environment, and increase the plastic that is being reused in products for the benefit of a circular economy.

Author Contributions: C.L.: Methodology, Investigation, Data Curation, Writing-Original Draft. P.A.: Conceptualization, Methodology, Resources, Writing-Review and Editing, Supervision, Project Administration, Funding Acquisition. All authors have read and agreed to the published version of the manuscript.

Funding: The authors thank New York's Environmental Protection Fund, the New York State Department of Environmental Conservation (NYSDEC), for financial support. The work was supported by a grant from NYSDEC to the University at Buffalo (UB), under Memorandum of Understanding AMI 1642. Research on plastic recycling in P.A.'s laboratory is supported by the US National Science Foundation (NSF) award 2029375 “EFRI E3P: Valorization of Plastic Waste via Advanced Separation and Processing.

Institutional Review Board Statement: Not applicable.

Informed Consent Statement: Not applicable.

Data Availability Statement: The data presented in this study are available on request from the corresponding author. The survey data are not publicly available due to privacy reasons.

Acknowledgments: The authors acknowledge useful discussions with Amit Goyal, Project Director of this grant, and with John D. Atkinson (UB Civil, Structural and Environmental Engineering), Michael Shelly (UB RENEW Institute), Aditya Vedantam (UB School of Management), as well as Amy Bloomfield, Terry Laibach, Jaime Lang, Gerard Wagner, and David Vitale at NYSDEC. John D. Atkinson and Michael Shelly provided valuable feedback on this document. We thank project team-members Jenna Mert, Austin Izzio, and Khadija Amal for their contribution in developing and administering the survey results that are reported here. We also thank all the industry professionals who participated in our survey or provided information through interviews.

Conflicts of Interest: The authors have no conflict of interest in regard to this work or any commercial association with the results of this work at this present time. 


\section{Appendix A}

Optical sorter supplier contact information.

\begin{tabular}{|c|c|}
\hline $\begin{array}{l}\text { Amut Ecotech } \\
\text { Via San Marco 11/a } \\
31052 \text { Candelù-Maserada sul Piave (TV)-Italy } \\
\text { Phone: }+390422877688 / 689 \\
\text { Fax +39 } 0422877690 \\
\text { E-mail: info@amutecotech.it Website: www.amutecotech.it (last accessed } 15 \\
\text { February 2022) }\end{array}$ & $\begin{array}{l}\text { Best } \\
\text { Contact details unavailble } \\
\text { Website: http:/ / best-sea.primary-engineering.co.th/recycling.html } \\
\text { www.amutecotech.it (last accessed } 16 \text { February 2022) }\end{array}$ \\
\hline $\begin{array}{l}\text { Binder }+ \text { Co } \\
\text { Grazer Straße 19-25 } \\
\text { A-8200 Gleisdorf, Austria } \\
\text { Phone: +43-3112-800-0 } \\
\text { Email: office@binder-co.at } \\
\text { www.binder-co.com } \\
\text { (last accessed } 12 \text { February 2022) }\end{array}$ & $\begin{array}{l}\text { BT-Wolfgang Binder GmbH (Redwave) } \\
\text { Wolfgang Binder Str. } 4 \\
8200 \text { Eggersdorf bei Graz, Austria } \\
\text { Phone: +43-3117-25152-2100 } \\
\text { E-mail: office@btw-plantsolutions.com } \\
\text { http:// www.btw-binder.com/en/ } \\
\text { (last accessed 12 February 2022) } \\
\text { www.redwave.com (last accessed } 12 \text { February 2022) }\end{array}$ \\
\hline $\begin{array}{l}\text { Buhler } \\
\text { Gupfenstrasse } 5 \\
\text { Uzwil } \\
9240 \text { Switzerland } \\
\text { Phone: } 4171951900 \\
\text { Website: https:// www.buhlergroup.com } \\
\text { (last accessed } 16 \text { February 2022) }\end{array}$ & $\begin{array}{l}\text { Cimbria } \\
\text { Faartoftvej 22 } \\
\text { 7700, Thisted, Denmark } \\
\text { Phone: +45-96-17-90-00 } \\
\text { E-mail: cimbria.holding@agcocorp.com } \\
\text { https: / wwww.cimbria.com } \\
\text { (last accessed } 12 \text { February 2022) }\end{array}$ \\
\hline $\begin{array}{l}\text { CP Group (MSS) Sorting Equipment } \\
\text { 795 Calle de Linea } \\
\text { San Diego, CA 92154, USA } \\
\text { Phone: } 19-477-3175 \\
\text { Fax: 619-477-3426 } \\
\text { https:// www.cpgrp.com } \\
\text { (last accessed 12 February 2022) }\end{array}$ & $\begin{array}{l}\text { Eagle Vizion } \\
425 \text { Boul. Industriel } \\
\text { Sherbrooke, QC Canada } \\
\text { Email: nlortie@eaglevizion } \\
\text { Phone: } 912-563-7374 \\
\text { Fax: } 819-340-1034 \\
\text { www.eaglevizion.com (last accessed } 12 \text { February 2022) }\end{array}$ \\
\hline $\begin{array}{l}\text { Green Machine LLC } \\
8300 \text { State Route 79 } \\
\text { Whitney Point, NY 13862-2504, U.S.A. } \\
\text { Phone: (800)-639-6306 } \\
\text { Email: ap@greenmachine.com } \\
\text { Website: www.greenmachine.com } \\
\text { (last accessed 12 February 2022) }\end{array}$ & $\begin{array}{l}\text { IMRO } \\
\text { Landwehrstrasse 2, } \\
\text { Uffenheim, D-97215, Germany } \\
\text { Phone: +49 (0) } 9848-9797-0 \\
\text { Email: 1uis@imro.us } \\
\text { Website: } h \text { htps: / / www.imro-maschinenbau.de/en/ } \\
\text { (last accessed } 12 \text { February 2022) }\end{array}$ \\
\hline $\begin{array}{l}\text { Mogensen GmbH/Allgaier Process Technology GmbH } \\
\text { Kronskamp } 126 \\
22880 \text { Wedel, Germany } \\
\text { Phone: +49-4103-8042-0 } \\
\text { E-mail: info@mogensen.de } \\
\text { https://www.allgaier-process-technology.com/de } \\
\text { (last accessed } 12 \text { February 2022) }\end{array}$ & $\begin{array}{l}\text { MSS, Inc. [A division of CP Group] } \\
\text { 300 Oceanside Drive } \\
\text { Nashville, TN 37204, U.S.A. } \\
\text { Phone: 615-781-2669 } \\
\text { Email: info@mssoptical.com } \\
\text { https://www.mssoptical.com } \\
\text { (last accessed } 12 \text { February 2022) }\end{array}$ \\
\hline $\begin{array}{l}\text { NRT } \\
1508 \text { Elm Hill Pike } \\
\text { Nashville, TN 37210, U.S.A. } \\
\text { Phone: } 1-1-615-734-6400 \\
\text { Emaill service@nttorters.com } \\
\text { www.nrtsorters.com (last accessed } 12 \text { February 2022) } \\
\end{array}$ & $\begin{array}{l}\text { Pellenc ST } \\
84-124 \text { Pertuis Cedex } 4 \\
\text { France } \\
\text { Phone: }+33-4-90-09-47-90 \\
\text { www.pellencst.com } \\
\text { (last accessed } 12 \text { February 2022) } \\
\end{array}$ \\
\hline $\begin{array}{l}\text { PicVisa } \\
\text { Isaac Newton, } 2 \\
\text { Barcelona, Spain } \\
\text { Phone: +34-93-868-08-45 } \\
\text { www.picvisa.com } \\
\text { (last accessed } 12 \text { February 2022) }\end{array}$ & $\begin{array}{l}\text { Rhewum GmbH } \\
\text { Rosentalstrasse } 24 \\
42899 \text { Remscheid, Germany } \\
\text { Phone: }+4921915767-0 \\
\text { Email: info@rhewum.de } \\
\text { Website: https:// wwww.rhewum.com/en Website: https://steinertglobal.com } \\
\text { (last accessed } 16 \text { February 2022) }\end{array}$ \\
\hline $\begin{array}{l}\text { Rofin Australia } \\
\text { 6/42-44 Garden Boulevard } \\
\text { Dingley Victoria } 3172 \\
\text { Australia } \\
\text { Phone: } 61395580344 \\
\text { Fax } 61395580252 \\
\text { E-mail: info@rofin.com.au } \\
\text { Website: http://www.rofin.com.au/index.htm } \\
\text { (last accessed 16 February 2022) }\end{array}$ & $\begin{array}{l}\text { Rofin USA } \\
\text { 696 San Ramon Valley Blvd. \#334 } \\
\text { Danville, CA } 94526 \\
\text { Phone: } 925-552-5922 \\
\text { Fax: 925-886-8833 } \\
\text { E-mail: keith@rofinusa.com } \\
\text { Website: http://www.rofin.com.au/index.htm } \\
\text { (last accessed 16 February 2022) }\end{array}$ \\
\hline $\begin{array}{l}\text { RTT Steinert GmbH } \\
\text { Widdersdorfer Str. 329-331 } \\
50933 \text { Köln, Germany } \\
\text { Phone: +49-221-49840 } \\
\text { Email: sales(at)steinert.de } \\
\text { Website: https://steinertglobal.com } \\
\text { (last accessed } 12 \text { February 2022) } \\
\end{array}$ & $\begin{array}{l}\text { Satake } \\
10900 \text { Cash Road } \\
\text { Stafford, Texas } 77477 \\
\text { USA } \\
\text { Phone: }+1 \text { (281) } 972-3581 \\
\text { Website: https: //satake-usa.com } \\
\text { (last accessed 16 February 2022) }\end{array}$ \\
\hline $\begin{array}{l}\text { Sesotec GmbH (S+S Separation and Sorting Technology GmbH) } \\
\text { Regener Strabe } 130 \\
\text { D-94513 Schonberg, Germany } \\
\text { Phone: }+49-8554-308-0 \\
\text { www. sesotec.com } \\
\text { (last accessed } 12 \text { February 2022) }\end{array}$ & $\begin{array}{l}\text { Steiner US } \\
285 \text { Shorland Drive } \\
\text { Jeremy Hundley } \\
\text { Phone: } 1 \text { ( } 859 \text { ) } 462-4878 \\
\text { Website: https://steinertglobal.com/us/ } \\
\text { (last accessed } 12 \text { February 2022) } \\
\end{array}$ \\
\hline $\begin{array}{l}\text { TiTech GmbH } \\
\text { Otto- Hahn-Stra } \beta \text { e } 6 \\
\text { 56218 Mülheim-Kälich, Germany } \\
\text { Email: wolf@titech.com } \\
\text { Phone: +1-203-524-3555 } \\
\text { Fax: +1-203-967-1199 } \\
\text { Website: www.titech.com } \\
\text { (last accessed 12 February 2022) }\end{array}$ & $\begin{array}{l}\text { TOMRA Systems ASA } \\
\text { Drengsrudhagen } 2 \\
\text { Asker } 1385 \\
\text { Norway } \\
\text { Phone: +47-66-79-91-00 } \\
\text { https://www.tomra.com/en } \\
\text { (last accessed } 12 \text { February 2022) }\end{array}$ \\
\hline $\begin{array}{l}\text { Unisensor Sensorsysteme GmbH } \\
\text { Am Sandfeld } 11 \\
76149 \text { Karlsruhe, Germany } \\
\text { Phone: +49-(721)-97884-0 } \\
\text { Email: info(at)unisensor.de } \\
\text { Website: www.unisensor.de/en/ } \\
\text { (last accessed } 12 \text { February 2022) }\end{array}$ & $\begin{array}{l}\text { Visys } \\
\text { Birlik Sanayi Sitesi 2. Cadde No:97 } \\
\text { 34520 Beylikdüzü-Istanbul-Turkey } \\
\text { Phone: +90-212-876-90-36 } \\
\text { Fax: +90-212-876-90-37 } \\
\text { E-mail: info@visystr.com } \\
\text { Website: www.visys.com.tr } \\
\text { (last accessed 12 February 2022) }\end{array}$ \\
\hline
\end{tabular}


Artificial intelligence-based sorter supplier contact information.

\begin{tabular}{|c|c|}
\hline $\begin{array}{l}\text { AMP Robotics } \\
1500 \text { Cherry Street, Suite A } \\
\text { Louisville, CO 80027, U.S.A } \\
\text { Phone: (888) } 402-1686 \\
\text { Website: } \text { www.amprobotics.com } \\
\text { (last accessed } 12 \text { February 2022) } \\
\end{array}$ & $\begin{array}{l}\text { Back Handling Systems (BHS) } \\
3592 \text { West 5th Avenue } \\
\text { Eugene, OR } 97402 \text {, U.S.A. } \\
\text { Phone: } 541.485 .0999 \\
\text { Website: https: / / www.bulkhandlingsystems.com } \\
\text { (last accessed } 12 \text { February 2022) }\end{array}$ \\
\hline $\begin{array}{l}\text { Bollegraaf Recycling Solutions } \\
\text { Tweede Industrieweg 1, } 9902 \mathrm{AM} \\
\text { Appingedam, Netherlands } \\
\text { Phone: +31-596-654-333 } \\
\text { Website: https: / / www.bollegraaf.com } \\
\text { (last accessed 12 February 2022) }\end{array}$ & $\begin{array}{l}\text { BT-Wolfgang Binder GmbH (Redwave) } \\
\text { Wolfgang Binder Str. } 4 \\
\text { 8200 Eggersdorf bei Graz, Austria } \\
\text { Phone: +43-3117-25152-2100 } \\
\text { E-mail: office@btw-plantsolutions.com } \\
\text { http://www.btw-binder.com//en/ } \\
\text { (last accessed 12 February 2022) }\end{array}$ \\
\hline $\begin{array}{l}\text { Machinex } \\
\text { 2121, Olivier Street Plessisville } \\
\text { QC, G6L 3G9 } \\
\text { Canada } \\
\text { Phone: +1-(819) 362-3281 } \\
\text { Website: www.machinexrecycling.com } \\
\text { (last accessed 12 February 2022) }\end{array}$ & $\begin{array}{l}\text { OP teknik } \\
\text { Truck path } 2 \\
29832 \text { Tollarp, Sweden } \\
\text { Phone: 010-456-82-87 } \\
\text { Website: https:/ www.opteknik.se/?lang=en } \\
\text { (last accessed 12 February 2022) }\end{array}$ \\
\hline $\begin{array}{l}\text { TOMRA Systems ASA } \\
\text { Drengsrudhagen } 2 \\
\text { Asker 1385, Norway } \\
\text { Phone: +47-66-79-91-00 } \\
\text { Website: https: / / www.tomra.com/en } \\
\text { (last accessed } 12 \text { February 2022) }\end{array}$ & \\
\hline
\end{tabular}

\section{Appendix B}

Survey questions used to obtain information from MRFs and reclaimers.

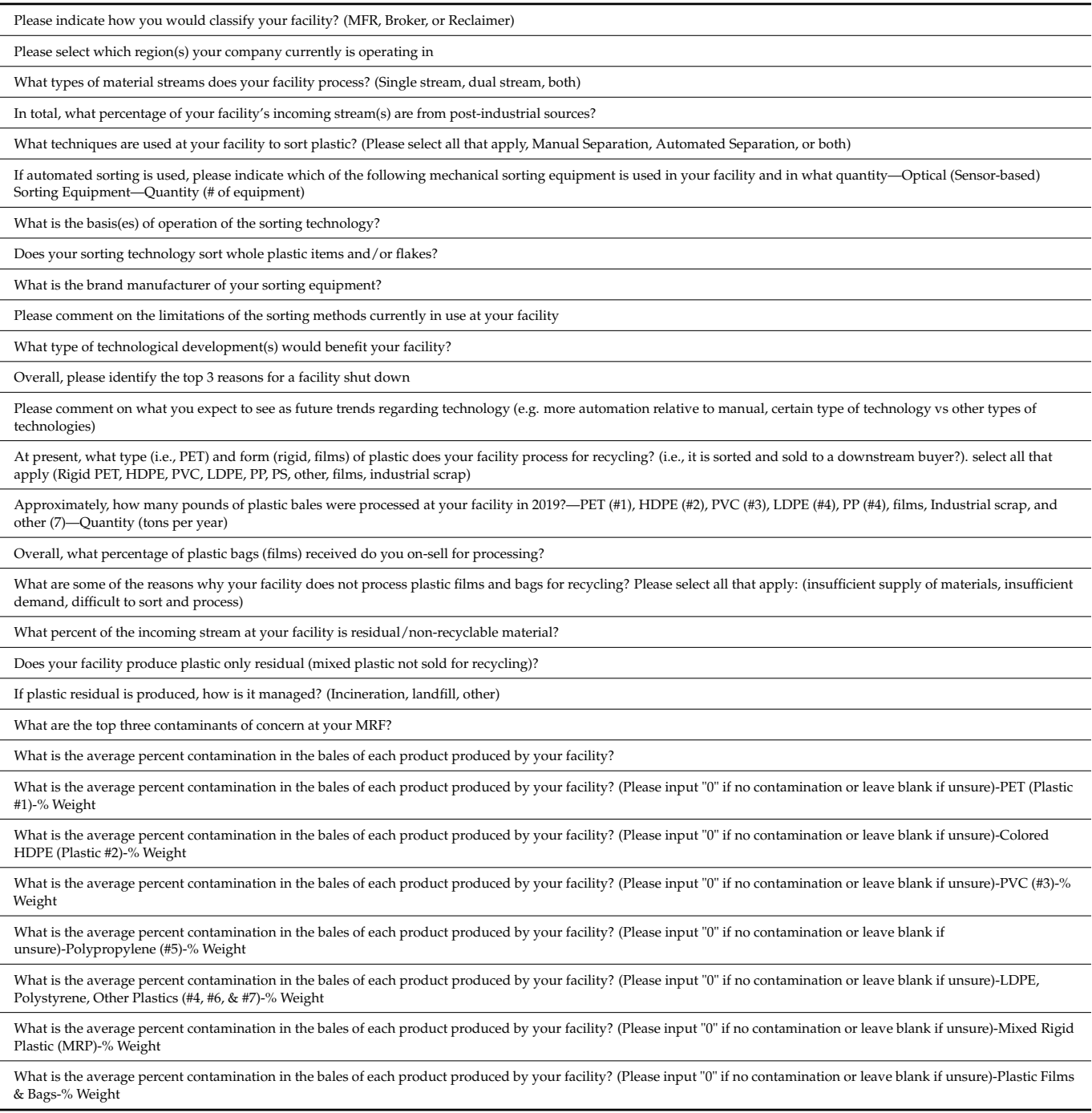




\section{References}

1. US Environmental Protection Agency. Facts and Figures about Materials, Waste and Recycling. Available online: https: //www.epa.gov/sites/default/files/2021-01/documents/2018_ff_fact_sheet_dec_2020_fnl_508.pdf (accessed on 19 June 2021).

2. Northfield, R. Despite Our Best Efforts, Plastic Is Still a Blight in our World. What Are We Doing Wrong? Available online: https:/ / eandt.theiet.org/content/articles/2019/03/the-problem-with-plastic/ (accessed on 12 February 2022).

3. Vollmer, I.; Jenks, M.J.F.; Roelands, M.C.P.; White, R.J.; van Harmelen, T.; de Wild, P.; van der Laan, G.P.; Meirer, F.; Keurentjes, J.T.F.; Weckhuysen, B.M. Beyond mechanical recycling: Giving new life to plastic waste. Angew. Chem. (Int. Ed. Engl.) 2020, 59, 15402-15423. [CrossRef]

4. da Silva, D.J.; Wiebeck, H. Current options for characterizing, sorting, and recycling polymeric waste. Prog. Rubber Plast. Recycl Technol. 2020, 36, 284-303. [CrossRef]

5. Lawrence, M.J. 10-Disposal of Plastics. In A Guide to the Manufacture, Performance, and Potential of Plastics in Agriculture; Orzolek, M.D., Ed.; Elsevier: Amsterdam, The Netherlands, 2017; pp. 187-195.

6. Brunner, S.; Fomin, P.; Kargel, C. Automated sorting of polymer flakes: Fluorescence labeling and development of a measurement system prototype. Waste Manag. 2015, 38, 49-60. [CrossRef]

7. Cimpan, C.; Maul, A.; Wenzel, H.; Pretz, T. Techno-economic assessment of central sorting at material recovery facilities-The case of lightweight packaging waste. J. Clean. Prod. 2016, 112, 4387-4397. [CrossRef]

8. Hundertmark, T.; Pietro, M.; Ryba, A.; Simons, T.J.; Wallach, J. Accelerating Plastic Recovery in the United States; McKinsey \& Company, U.S.A, 2019. Available online: https:/ / www.mckinsey.com/industries/chemicals/our-insights/accelerating-plasticrecovery-in-the-united-states (accessed on 12 February 2022).

9. Damgacioglu, H.; Hornilla, M.; Bafail, O.; Celik, N. Recovering value from single stream material recovery facilities-An outbound contamination analysis in Florida. Waste Manag. 2020, 102, 804-814. [CrossRef]

10. American Chemistry Council. 2018 United States National Postconsumer Plastic Bottle Recycling Report. 2018. Available online: https:/ / plasticsrecycling.org/images/library/2018-postconsumer-bottle-recycling-report.pdf (accessed on 12 February 2022).

11. Vedantam, A.; Shelly, M.; Ajmal, K. Evaluating Secondary Market Conditions for Plastic Recyclables, Assessment of Processing Capacity in NYS and the U.S.; University at Buffalo, The State University of New York: Buffalo, NY, USA, 2021.

12. Bledzki, A.K.; Goracy, K. Installations to sort packaging plastics wastes. Polimery 1998, 43, 1-10. [CrossRef]

13. Gundupalli, S.P.; Hait, S.; Thakur, A. A review on automated sorting of source-separated municipal solid waste for recycling. Waste Manag. 2017, 60, 56-74. [CrossRef]

14. Maulidati, N.; Cahyo, A.D.N.; Djamari, D.W.; Fikri, M.R.; Triawan, F. Development of sorting system for plastic bottle waste management. IOP Conf. Series. Mater. Sci. Eng. 2021, 1098, 062103. [CrossRef]

15. Kim, J.; Nocentini, O.; Scafuro, M.; Limosani, R.; Manzi, A.; Dario, P.; Cavallo, F. An innovative automated robotic system based on deep learning approach for recycling objects. In Proceedings of the 16th International Conference on Informatics in Control, Automation and Robotics (ICINCO), Prague, Czech Republic, 29-31 July 2019; pp. 613-622.

16. Wilts, H.; Garcia, B.R.; Garlito, R.G.; Gomez, L.S.; Prieto, E.G. Artificial intelligence in the sorting of municipal waste as an enabler of the circular economy. Resources 2021, 10, 28. [CrossRef]

17. Alexander, D. Design of a Materiasl Recovery Facility (MRF) For Processing The Recyclable Materials of New York City Municipal Solid Waste; Columbia University: New York, NY, USA, 2000.

18. Vrancken, C.; Longhurst, P.J.; Wagland, S.T. Critical review of real-time methods for solid waste characterisation: Informing material recovery and fuel production. Waste Manag. 2017, 61, 40-57. [CrossRef]

19. 4R Sustainability Inc. Demingling the Mix: An Assessment of Commercially Available Automated Sorting Technology. 2011. Available online: https://www.polyester-technology.com/download/demingling-the-mix-an-assessment-of-commerciallyavailable-automated-sorting-technology-4/?wpdmdl=604\&refresh=612e6f490214d1630433097 (accessed on 12 October 2020).

20. Delavelle, C. State of the Art of Waste Identification and Sorting Technology. 2012. Available online: https://www.ademe.fr/ sites/default/files/assets/documents/87753_rapport-ajeurope-technologies-de-tri.pdf (accessed on 12 February 2022).

21. US Environmental Protection Agency. The National Recycling Goal; US Environmental Protection Agency: Washington, DC, USA, 2020. Available online: https://www.epa.gov/sites/default/files/2020-12/documents/final_one_pager_to_print_508.pdf (accessed on 12 February 2022).

22. Eriksen, M.K.; Damgaard, A.; Boldrin, A.; Astrup, T.F. Quality assessment and circularity potential of recovery systems for household plastic waste. J. Ind. Ecol. 2019, 23, 156-168. [CrossRef]

23. Vogt, B.D.; Stokes, K.K.; Kumar, S.K. Why is recycling of postconsumer plastics so challenging? ACS Appl. Polym. Mater. 2021, 3, 4325-4346. [CrossRef]

24. Cimpan, C.; Maul, A.; Jansen, M.; Pretz, T.; Wenzel, H. Central sorting and recovery of MSW recyclable materials: A review of technological state-of-the-art, cases, practice and implications for materials recycling. J. Environ. Manag. 2015, 156, 181-199. [CrossRef]

25. Araujo-Andrade, C.; Bugnicourt, E.; Philippet, L.; Rodriguez-Turienzo, L.; Nettleton, D.; Hoffmann, L.; Schlummer, M. Review on the photonic techniques suitable for automatic monitoring of the composition of multi-materials wastes in view of their posterior recycling. Waste Manag. Res. 2021, 39, 631-651. [CrossRef] 
26. Siddappaji, K.; Sujatha, K.; Radha, R.C. Technologies for segregation and management of solid waste: A review. In Proceedings of the 2016 International Conference on Emerging Trends in Engineering, Technology and Science (ICETETS), Pudukkottai, India, 24-26 February 2016; pp. 1-4.

27. Henriksen, M.L.; Karlsen, C.B.; Klarskov, P.; Hinge, M. Plastic classification via in-line hyperspectral camera analysis and unsupervised machine learning. Vib. Spectrosc. 2022, 118, 103329. [CrossRef]

28. Zheng, Y.; Bai, J.R.; Xu, J.N.; Li, X.Y.; Zhang, Y.M. A discrimination model in waste plastics sorting using NIR hyperspectral imaging system. Waste Manag. 2018, 72, 87-98. [CrossRef]

29. Cucuzza, P.; Serranti, S.; Bonifazi, G.; Capobianco, G. Effective recycling solutions for the production of high-quality PET flakes based on hyperspectral imaging and variable selection. J. Imaging 2021, 7, 181. [CrossRef]

30. $\mathrm{Wu}, \mathrm{X}$.; Li, J.; Yao, L.; Xu, Z. Auto-sorting commonly recovered plastics from waste household appliances and electronics using near-infrared spectroscopy. J. Clean. Prod. 2020, 246, 118732. [CrossRef]

31. Weiss, M. XRF-New Applications in Sensor-Based-Sorting Using X-ray Fluorescence. 2012. Available online: https:/ /www.vivis. de/wp-content/uploads/WM3/2012_WM_139_148_Weiss.pdf (accessed on 12 February 2022).

32. Shimadzu. UV-Vis Frequently Asked Questions-Light and Theory. Available online: https://www.ssi.shimadzu.com/products/ uv-vis-spectrophotometers/faqs/light-and-theory.html (accessed on 24 May 2021).

33. Bonifazi, G.; Serranti, S. Quality control by HyperSpectral Imaging (HSI) in solid waste recycling: Logics, algorithms and procedures. Proc. SPIE 2014, 9024, 90240T.

34. Kuppers, B.; Schloegl, S.; Oreski, G.; Pomberger, R.; Vollprecht, D. Influence of surface roughness and surface moisture of plastics on sensor-based sorting in the near infrared range. Waste Manag. Res. 2019, 37, 843-850. [CrossRef]

35. Ramasubramanian, M.K.; Venditti, R.A.; Ammineni, C.; Mallapragada, V. Optical sensor for noncontact measurement of lignin content in high-speed moving paper surfaces. IEEE Sens. J. 2005, 5, 1132-1139. [CrossRef]

36. Bezati, F.; Froelich, D.; Massardier, V.; Maris, E. Addition of X-ray fluorescent tracers into polymers, new technology for automatic sorting of plastics: Proposal for selecting some relevant tracers. Resour. Conserv. Recycl. 2011, 55, 1214-1221. [CrossRef]

37. Torres-García, A.; Rodea-Aragón, O.; Longoria-Gandara, O.; Sánchez-García, F.; González-Jiménez, L.E. Intelligent waste separator. Comput. Sist. 2015, 19, 487-500. [CrossRef]

38. Meert, J.; Izzo, A.; Atkinson, J.D. Impact of plastic bag bans on retail return polyethylene film recycling contamination rates and speciation. Waste Manag. 2021, 135, 234-242. [CrossRef]

39. Debrecht, S. Recycle Right: Designing Tools for Resource Responsible Consumers. Ph.D. Thesis, University of Cincinnati, Cincinnati, OH, USA, 2021.

40. Soto, J.M.; Blazquez, G.; Calero, M.; Quesada, L.; Godoy, V.; Martin-Lara, M.A. A real case study of mechanical recycling as an alternative for managing of polyethylene plastic film presented in mixed municipal solid waste. J. Clean. Prod. 2018, 203, 777-787. [CrossRef]

41. Turner, A. Black plastics: Linear and circular economies, hazardous additives and marine pollution. Environ. Int. 2018, 117, 308-318. [CrossRef]

42. Becker, W.; Sachsenheimer, K.; Klemenz, M. Detection of black plastics in the middle infrared spectrum (MIR) using photon up-conversion technique for polymer recycling purposes. Polymers 2017, 9, 435. [CrossRef]

43. Vedantam, A.; Ajmal, K.; Shelly, M. Impact of China's National Sword Policy on the Plastics Recycling Industry in the U.S.; University at Buffalo, The State University of New York: Buffalo, NY, USA, 2021.

44. Feil, A.; Pretz, T.; Jansen, M.; Thoden van Velzen, E.U. Separate collection of plastic waste, better than technical sorting from municipal solid waste? Waste Manag. Res. 2016, 35, 172-180. [CrossRef]

45. Chin, L.; Lipton, J.; Yuen, M.C.; Kramer-Bottiglio, R.; Rus, D. Automated recycling separation enabled by soft robotic material classification. In Proceedings of the 2019 2nd IEEE International Conference on Soft Robotics (RoboSoft), Seoul, Korea, 14-18 April 2019; pp. 102-107.

46. Sarc, R.; Curtis, A.; Kandlbauer, L.; Khodier, K.; Lorber, K.E.; Pomberger, R. Digitalisation and intelligent robotics in value chain of circular economy oriented waste management-A review. Waste Manag. 2019, 95, 476-492. [CrossRef]

47. Bobulski, J.; Kubanek, M. Deep learning for plastic waste classification system. Appl. Comput. Intell. Soft Comput. 2021, 2021, 6626948. [CrossRef]

48. Sirawattananon, C.; Muangnak, N.; Pukdee, W. Designing of IoT-based smart waste sorting system with image-based deep learning applications. In Proceedings of the 2021 18th International Conference on Electrical Engineering/Electronics, Computer, Telecommunications and Information Technology (ECTI-CON), Chiang Mai, Thailand, 19-22 May 2021; pp. $383-387$. 